\title{
A strategy to prepare peptide heterodimers in the solid phase with an acid-labile linker
}

Gang Wang ${ }^{1}$, Tingting Chen $^{1}$, Tao Peng ${ }^{1}$, Shouguo Zhang ${ }^{1}$, Junyi Wang ${ }^{3}$, Xiaoxue Wen ${ }^{1}$, Xiaoming Yang $^{2, \dagger}$, Lin Wang ${ }^{1, *}$

1. Beijing institute of Radiation Medicine, Beijing, 100850, PR China

2. Beijing institute of Lifeomics, Beijing, 102206, PR China

3. College of Engineering, Peking University, Beijing, 100871, PR China

\section{GENERATION INFORMATION}

All reagents and amino acids were purchased from Beijing Innochem Science and Technology Co. Ltd. Room temperature (r.t) refers to ambient temperature. Solid-phase synthesis was carried out manually in polypropylene syringe containing a polyethylene frit. Unless specified, all reagents were commercially available without further purification. DMF was distilled from $\mathrm{P}_{2} \mathrm{O}_{5}$. The visualization of TLC was performed with UV light. Flash column chromatography was performed on silica gel (200-300 mesh).

${ }^{1} \mathrm{H}$ NMR and ${ }^{13} \mathrm{C}$ NMR were recorded by JEOL FT-NMR spectrometer at 400 and $150 \mathrm{MHz}$, respectively. High resolution mass spectrometry (HRMS) of linker and intermediate measurements were recorded with ESI-TOF by Agilent 1260- G6230A spectrometer. Analytical high-pressure liquid chromatography (HPLC) was carried out on an Agilent instrument (Agilent 1100), automatic injector, photodiode array detector, and system controller (Empower login). A Venusil ASB C18 column ( $5 \mu \mathrm{m}, 150 \mathrm{~mm} \times 4.6 \mathrm{~mm}$, Bonna-Agela Technologies, Tianjin, China) was used for analysis. A Venusil ASB C18 column ( $5 \mu \mathrm{m}, 150 \mathrm{~mm} \times 25 \mathrm{~mm}$, Bonna-Agela Technologies, Tianjin, China) was used for preparation. UV measurements were recorded at $220 \mathrm{~nm}$. $\mathrm{H}_{2} \mathrm{O}$ (containing $0.1 \%$ TFA) and pure acetonitrile (containing $0.1 \%$ TFA) were used as solvents in linear gradient mixtures. High resolution mass spectra of peptide were carried out on a Bruker 9.4T QFT-ICR-MS.

\section{SYNTHESIS OF LINKER}
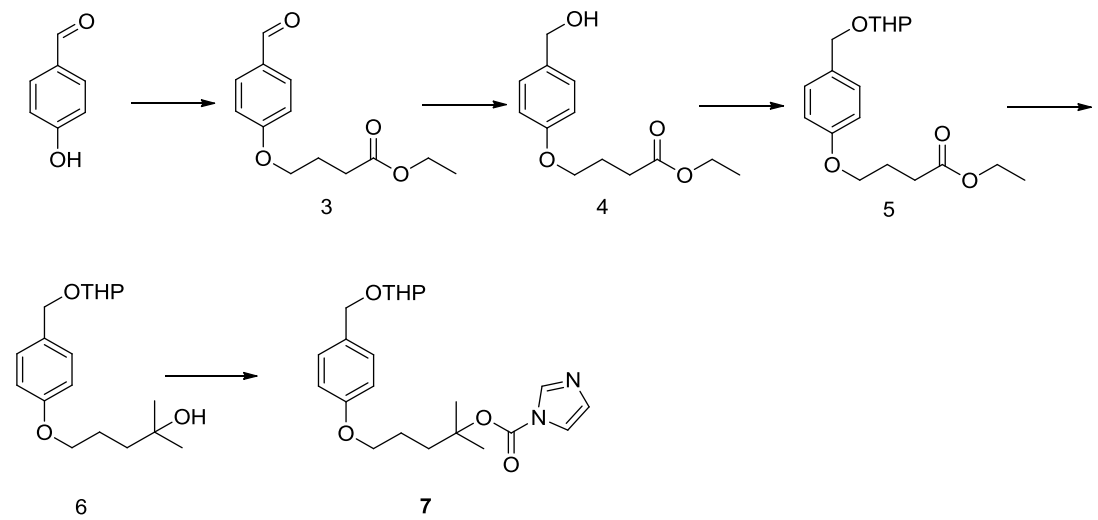

\section{1 ethyl 4-(4-formylphenoxy) butanoate (3)}

To a solution of 4-hydroxybenzaldehyde $(6.11 \mathrm{~g}, 50 \mathrm{mmol})$ in $180 \mathrm{~mL} \mathrm{CH} 3 \mathrm{CN}$ was added ethyl 4-bromobutyrate $(10.70 \mathrm{~g}, 55 \mathrm{mmol})$ and anhydrous $\mathrm{K}_{2} \mathrm{CO}_{3}(13.80 \mathrm{~g}, 100 \mathrm{mmol})$, the mixture was heated to reflux until the reaction was completed. The resulting solution was cooled to ambient temperature, the insoluble substance was removed by filtration and washed with $\mathrm{CH}_{3} \mathrm{CN}$, the organic phase was combined. The solvent was removed under vacuum, and the crude product was purified by column chromatography (hexane: EtOAc $=3: 1)$ to give $10.92 \mathrm{~g}(46.3 \mathrm{mmol}, 92.5 \%)$ of $(\mathbf{3})$ as a colorless 
oil. ${ }^{1} \mathrm{H}$ NMR (400 MHz, $\left.\mathrm{CDCl}_{3}\right) \delta 9.86(\mathrm{~s}, 1 \mathrm{H}), 7.85-7.76(\mathrm{~m}, 2 \mathrm{H}), 7.01-6.92(\mathrm{~m}, 2 \mathrm{H}), 4.19-4.02(\mathrm{~m}, 4 \mathrm{H}), 2.51(\mathrm{t}, J=$ $7.3 \mathrm{~Hz}, 2 \mathrm{H}), 2.19-2.08(\mathrm{~m}, 2 \mathrm{H}), 1.25(\mathrm{t}, J=7.1 \mathrm{~Hz}, 3 \mathrm{H}) .{ }^{13} \mathrm{C} \mathrm{NMR}\left(101 \mathrm{MHz}, \mathrm{CDCl}_{3}\right) \delta 190.95,173.11,163.96,132.10$, 130.01, 114.81, 67.20, 60.66, 30.68, 24.48, 14.31. MS calculated for $\mathrm{C}_{13} \mathrm{H}_{16} \mathrm{O}_{4}[\mathrm{M}+\mathrm{H}]^{+}: \mathrm{m} / \mathrm{z}$ 237.1121; found: 237.1120.

\section{2 ethyl 4-(4-(hydroxymethyl) phenoxy) butanoate (4)}

To a solution of (3) dissolved in $200 \mathrm{~mL} \mathrm{EtOH}$ was added $1.89 \mathrm{~g} \mathrm{NaBH}_{4}$ in portions under ice bath, the resulting solution was stirred at $0{ }^{\circ} \mathrm{C}$ for $30 \mathrm{~min}$ and continue react in r.t for $2 \mathrm{~h}$. The reaction was concentrated and quenched with citric acid solution. The aqueous layers were extracted with ethyl acetate $(3 \times 100 \mathrm{~mL})$. The organic portion was washed with saturated brine $(3 \times 100 \mathrm{~mL})$ and combined, dried over $\mathrm{MgSO}_{4}$. The solvent was removed under vacuum to give the corresponding alkoxy benzyl alcohol (4) as colorless oil. The product was used directly without further purification. ${ }^{1} \mathrm{H}$ NMR (400 MHz, DMSO-d $) \delta 7.24-7.14(\mathrm{~m}, 2 \mathrm{H}), 6.84(\mathrm{dd}, J=11.7,8.3 \mathrm{~Hz}, 2 \mathrm{H}), 4.37(\mathrm{t}, J=2.6 \mathrm{~Hz}, 2 \mathrm{H}), 4.03(\mathrm{q}, J=$ $7.1 \mathrm{~Hz}, 2 \mathrm{H}), 3.92(\mathrm{t}, J=6.3 \mathrm{~Hz}, 2 \mathrm{H}), 2.41(\mathrm{t}, J=7.3 \mathrm{~Hz}, 2 \mathrm{H}), 1.92(\mathrm{p}, J=6.8 \mathrm{~Hz}, 2 \mathrm{H}), 1.14(\mathrm{t}, J=7.1 \mathrm{~Hz}, 3 \mathrm{H}) .{ }^{13} \mathrm{C}$ NMR $\left(101 \mathrm{MHz}, \mathrm{DMSO}-d_{6}\right) \delta 173.09,158.41,157.86,135.11,130.93,129.72,128.44,114.67,114.52,71.29,66.91,63.07$, 60.40, 30.66, 24.78, 14.62. MS calculated for $\mathrm{C}_{13} \mathrm{H}_{18} \mathrm{O}_{4}$ [M+Na] +: m/z 261.1097; found: 261.1097.

\section{3 ethyl 4-(4-(((tetrahydro-2H-pyran-2-yl) oxy) methyl) phenoxy) butanoate (5)}

The compound (4) was dissolved in $200 \mathrm{~mL}$ anhydrous $\mathrm{CH}_{2} \mathrm{Cl}_{2}, 5.04 \mathrm{~g} \mathrm{3,4-Dihydro-2H-pyran} \mathrm{(DHP,} 60 \mathrm{mmol}$ ) was added, the solution was stirred at r.t for $10 \mathrm{~min}$, then $0.20 \mathrm{~g}$ TsOH was added in one portion to catalyst the reaction. After $30 \mathrm{~min}$, the reaction was completed, $100 \mathrm{~mL} \mathrm{CH}_{2} \mathrm{Cl}_{2}$ was added to dilute the reaction and wash with saturated $\mathrm{Na}_{2} \mathrm{CO}_{3}$ solution $(3 \times 100 \mathrm{~mL})$ and saturated brine $(3 \times 100 \mathrm{~mL})$. The organic layer was separated and dried over $\mathrm{MgSO}_{4}$. The solvent was removed under vacuum and the residue was purified by column chromatography (hexane: EtOAc $=6: 1$ ) to give $12.25 \mathrm{~g}\left(38.0 \mathrm{mmol}, 87.5 \%\right.$ for two steps from 3) of (5) as a colorless oil. ${ }^{1} \mathrm{H}$ NMR (400 MHz, DMSO- $\left.d_{6}\right) \delta 7.25-$ $7.16(\mathrm{~m}, 2 \mathrm{H}), 6.89-6.81(\mathrm{~m}, 2 \mathrm{H}), 4.63-4.58(\mathrm{~m}, 1 \mathrm{H}), 4.55(\mathrm{~d}, J=11.6 \mathrm{~Hz}, 1 \mathrm{H}), 4.31(\mathrm{~d}, J=11.6 \mathrm{~Hz}, 1 \mathrm{H}), 4.03(\mathrm{q}, J=$ $7.2 \mathrm{~Hz}, 2 \mathrm{H}), 3.93(\mathrm{t}, J=6.4 \mathrm{~Hz}, 2 \mathrm{H}), 3.75(\mathrm{~m}, J=11.4,8.2,3.3 \mathrm{~Hz}, 1 \mathrm{H}), 3.43(\mathrm{~m}, J=11.1,4.8,1.4 \mathrm{~Hz}, 1 \mathrm{H}), 2.42(\mathrm{q}, J=$ $7.6 \mathrm{~Hz}, 3 \mathrm{H}), 1.98-1.87(\mathrm{~m}, 2 \mathrm{H}), 1.78-1.53(\mathrm{~m}, 2 \mathrm{H}), 1.52-1.35(\mathrm{~m}, 4 \mathrm{H}), 1.14(\mathrm{t}, J=7.1 \mathrm{~Hz}, 2 \mathrm{H}) .{ }^{13} \mathrm{C}$ NMR $(101 \mathrm{MHz}$, DMSO- $\left.d_{6}\right) \delta 173.09,158.39,130.74,129.84,114.68,97.49,68.24,66.94,61.78,60.40,30.72,30.66,30.44,25.57,24.74$, 19.61, 14.64. MS calculated for $\mathrm{C}_{18} \mathrm{H}_{26} \mathrm{O}_{5}[\mathrm{M}+\mathrm{Na}]^{+}: \mathrm{m} / \mathrm{z} 345.1672$; found: 345.1673 .

\subsection{2-methyl-5-(4-(((tetrahydro-2H-pyran-2-yl) oxy) methyl) phenoxy) pentan-2-ol (6)}

$9.66 \mathrm{~g}(30 \mathrm{mmol})(\mathbf{5})$ dissolved in $100 \mathrm{~mL}$ anhydrous THF was capped with rubber seal and stirred under $0{ }^{\circ} \mathrm{C} .35 \mathrm{~mL}$ $\mathrm{CH}_{3} \mathrm{MgBr}$ solution (3M in ether) was added via syringe over $10 \mathrm{~min}$, and stirred at $0{ }^{\circ} \mathrm{C}$ for $30 \mathrm{~min}$. The reaction was continue stirred in r.t for further $3 \mathrm{~h}$. The reaction was re-cooled to $0{ }^{\circ} \mathrm{C}$ and quenched by saturated $\mathrm{NH}_{4} \mathrm{Cl}$ solution until $\mathrm{pH}<4$. The aqueous layers were extracted with ethyl acetate $(3 \times 100 \mathrm{~mL})$. The organic portion was washed with saturated brine $(3 \times 100 \mathrm{~mL})$ and combined, dried over $\mathrm{MgSO}_{4}$. The solvent was removed under vacuum and the residue was purified by column chromatography (hexane: EtOAc $=3: 1)$ to give $9.12 \mathrm{~g}(29.6 \mathrm{mmol}, 98.7 \%)$ of (6) as a light-yellow oil. ${ }^{1} \mathrm{H}$ NMR $\left(400 \mathrm{MHz}, \mathrm{DMSO}-d_{6}\right) \delta 7.24-7.16(\mathrm{~m}, 2 \mathrm{H}), 6.89-6.81(\mathrm{~m}, 2 \mathrm{H}), 4.60(\mathrm{t}, J=3.7 \mathrm{~Hz}, 1 \mathrm{H}), 4.55(\mathrm{~d}, J=11.5 \mathrm{~Hz}, 1 \mathrm{H}), 4.31$ $(\mathrm{d}, J=11.5 \mathrm{~Hz}, 1 \mathrm{H}), 4.17(\mathrm{~s}, 1 \mathrm{H}), 3.90(\mathrm{t}, J=6.6 \mathrm{~Hz}, 2 \mathrm{H}), 3.75(\mathrm{~m}, J=11.4,8.2,3.3 \mathrm{~Hz}, 1 \mathrm{H}), 3.48-3.38(\mathrm{~m}, 1 \mathrm{H}), 1.77-$ $1.63(\mathrm{~m}, 3 \mathrm{H}), 1.59(\mathrm{td}, J=9.4,3.0 \mathrm{~Hz}, 1 \mathrm{H}), 1.52-1.36(\mathrm{~m}, 6 \mathrm{H}), 1.06(\mathrm{~s}, 6 \mathrm{H}) .{ }^{13} \mathrm{C}$ NMR $\left(101 \mathrm{MHz}, \mathrm{DMSO}-d_{6}\right) \delta 158.66$, $130.51,129.84,114.66,97.49,69.07,68.63,68.27,61.77,30.72,29.86,25.57,24.48,19.61$. MS calculated for $\mathrm{C}_{18} \mathrm{H}_{28} \mathrm{O}_{4}$ $[\mathrm{M}+\mathrm{Na}]^{+}: \mathrm{m} / \mathrm{z} 331.1880$; found: 331.1883 .

\subsection{2-methyl-5-(4-(((tetrahydro-2H-pyran-2-yl) oxy) methyl) phenoxy) pentan-2-yl 1H-imidazole-1-carboxylate (7)}

To a solution of $1.54 \mathrm{~g}(5 \mathrm{mmol})$ (6) dissolved in $25 \mathrm{~mL}$ toluene was added $1.30 \mathrm{~g}(8 \mathrm{mmol}) \mathrm{CDI}$, the suspension was stirred at r.t for $10 \mathrm{~min}$ then heated to $80 \mathrm{C}^{\circ}$ for $6 \mathrm{~h}$. TLC indicated that the reaction was completed. The solvent was removed under vacuum, $60 \mathrm{~mL} \mathrm{CH}_{2} \mathrm{Cl}_{2}$ was added to dissolve the residue and wash with $\mathrm{H}_{2} \mathrm{O}(3 \times 50 \mathrm{~mL})$ and saturated brine $(3 \times 50 \mathrm{~mL})$. The organic layer was separated and dried over $\mathrm{MgSO}_{4}$. The solvent was removed under vacuum and the residue was purified by column chromatography (hexane: EtOAc $=1: 1)$ to give $1.86 \mathrm{~g}(4.6 \mathrm{mmol}, 92.5 \%)$ of $(7)$ as a light-yellow oil. ${ }^{1} \mathrm{H} \mathrm{NMR}\left(400 \mathrm{MHz}, \mathrm{CDCl}_{3}\right) \delta 8.08(\mathrm{t}, J=1.1 \mathrm{~Hz}, 1 \mathrm{H}), 7.34$ (q, $\left.J=1.9,1.5 \mathrm{~Hz}, 1 \mathrm{H}\right), 7.31-7.23$ (m, 2H), 
$7.03(\mathrm{t}, J=1.4 \mathrm{~Hz}, 1 \mathrm{H}), 6.88-6.80(\mathrm{~m}, 2 \mathrm{H}), 4.74-4.64(\mathrm{~m}, 2 \mathrm{H}), 4.42(\mathrm{~d}, J=11.6 \mathrm{~Hz}, 1 \mathrm{H}), 3.98(\mathrm{t}, J=6.1 \mathrm{~Hz}, 2 \mathrm{H}), 3.91$ $(\mathrm{m}, J=11.5,8.1,3.2 \mathrm{~Hz}, 1 \mathrm{H}), 3.58-3.48(\mathrm{~m}, 1 \mathrm{H}), 2.11-2.02(\mathrm{~m}, 2 \mathrm{H}), 1.94-1.47(\mathrm{~m}, 14 \mathrm{H}) .{ }^{13} \mathrm{C} \mathrm{NMR}\left(101 \mathrm{MHz}, \mathrm{CDCl}_{3}\right)$ $\delta 158.39,147.07,137.11,130.56,130.38,129.63,117.20,114.39,97.58,87.55,68.56,67.53,62.26,37.43,30.68,25.88$, 25.57, 24.05, 19.52. MS calculated for $\mathrm{C}_{22} \mathrm{H}_{30} \mathrm{~N}_{2} \mathrm{O}_{5}[\mathrm{M}+\mathrm{H}]^{+}: \mathrm{m} / \mathrm{z}$ 403.2227; found:403.2227. 
3. CHARACTERIZATION DATA OF THE PRODUCTS

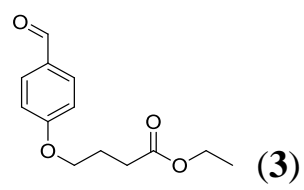

${ }^{1} \mathrm{H}$ NMR $\left(400 \mathrm{MHz}, \mathrm{CDCl}_{3}\right) \delta 9.86(\mathrm{~s}, 1 \mathrm{H}), 7.85-7.76(\mathrm{~m}, 2 \mathrm{H}), 7.01-6.92(\mathrm{~m}, 2 \mathrm{H}), 4.19-4.02(\mathrm{~m}, 4 \mathrm{H}), 2.51(\mathrm{t}, J=7.3$ $\mathrm{Hz}, 2 \mathrm{H}), 2.19-2.08(\mathrm{~m}, 2 \mathrm{H}), 1.25(\mathrm{t}, J=7.1 \mathrm{~Hz}, 3 \mathrm{H})$.

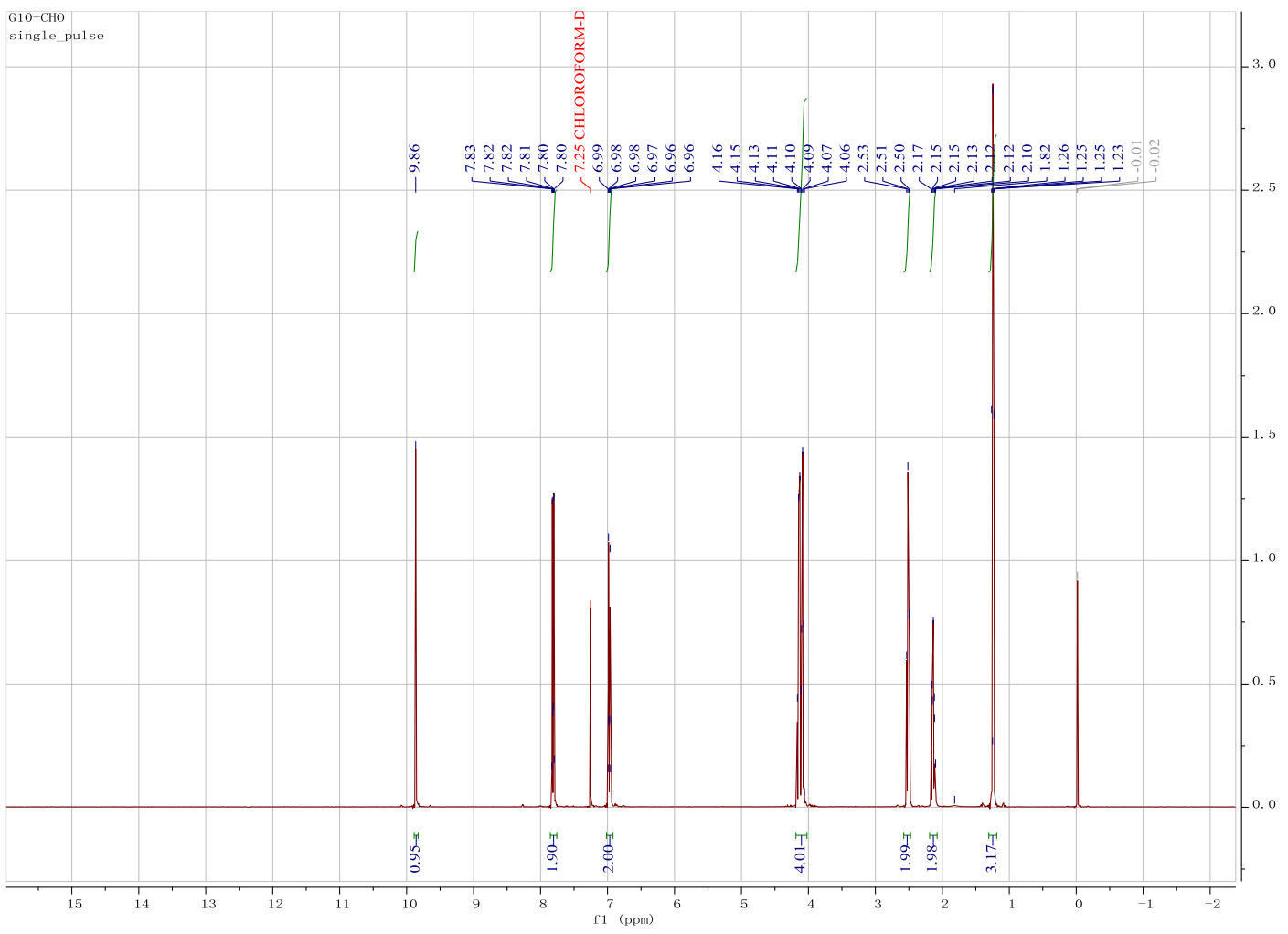


${ }^{13} \mathrm{C} \mathrm{NMR}\left(101 \mathrm{MHz}, \mathrm{CDCl}_{3}\right) \delta 190.95,173.11,163.96,132.10,130.01,114.81,67.20,60.66,30.68,24.48,14.31$.

G10-CHO

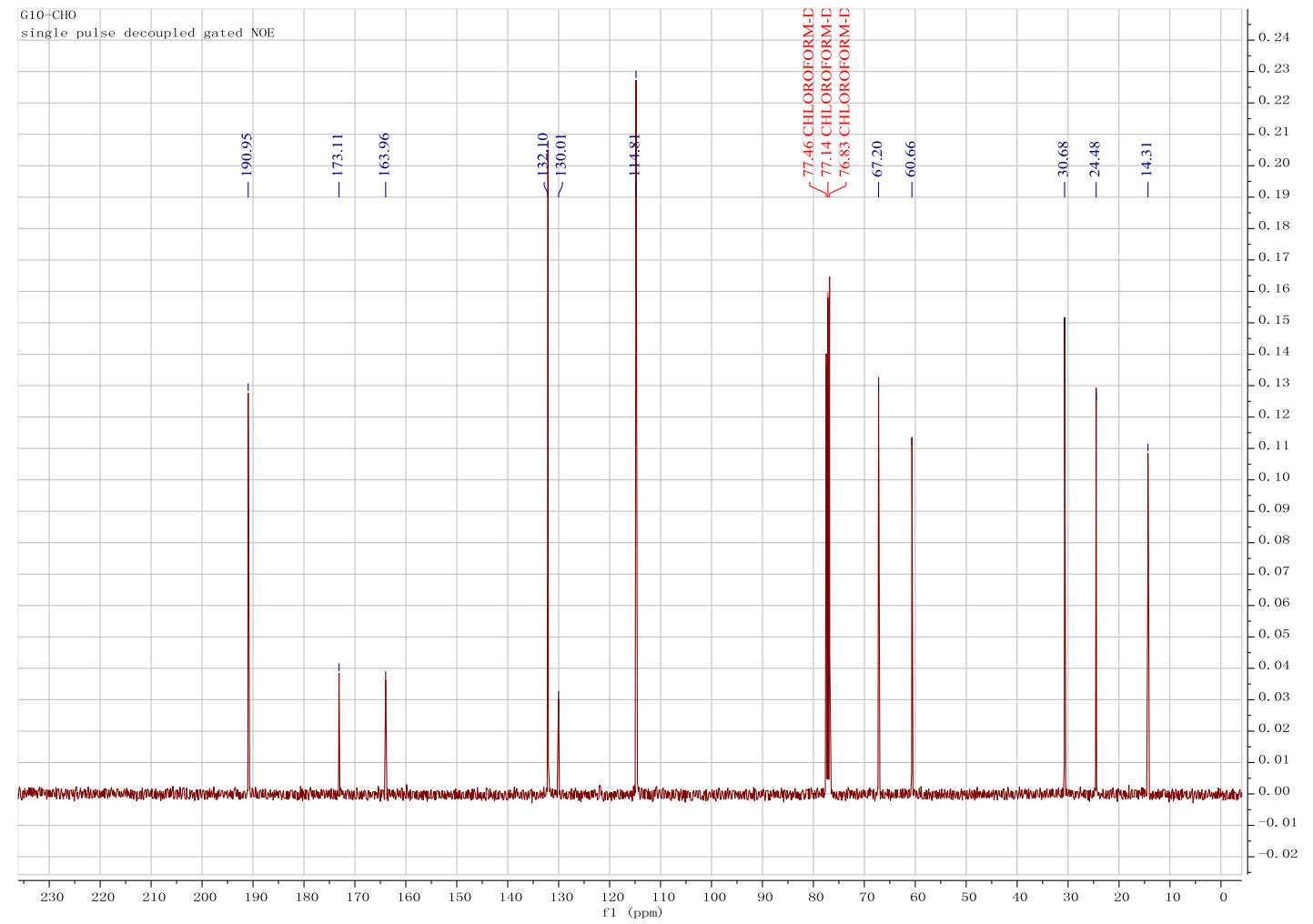

MS calculated for $\mathrm{C}_{13} \mathrm{H}_{16} \mathrm{O}_{4}[\mathrm{M}+\mathrm{H}]^{+}: \mathrm{m} / \mathrm{z} 237.1121$; found: 237.1120

Qualitative Analysis Report

\begin{tabular}{llll} 
& & & \\
Data Filename & 2338.d & Sample Name & G10-CHO \\
Instrument Name & TOFG6230A & Acquired Time & 2019-03-15 \\
Acq Method & YCL.M & Acquired SW & 6200 series TOF/6500 series \\
IRM Calibration Status & Success & & \\
User Chormatograms & & & \\
\hline
\end{tabular}

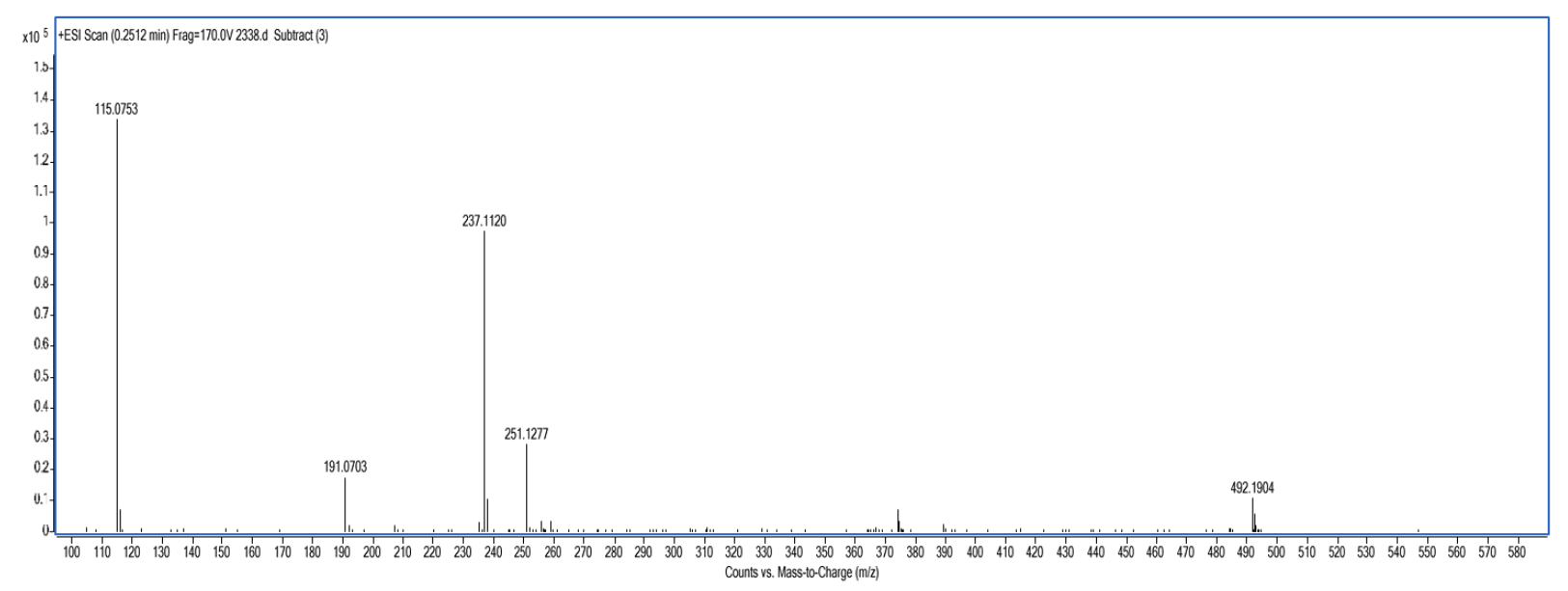


${ }^{1} \mathrm{H}$ NMR (400 MHz, DMSO- $d_{6}$ ) $\delta 7.24-7.14$ (m, 2H), 6.84 (dd, $\left.J=11.7,8.3 \mathrm{~Hz}, 2 \mathrm{H}\right), 4.37$ (t, $\left.J=2.6 \mathrm{~Hz}, 2 \mathrm{H}\right), 4.03$ (q, $J$ $=7.1 \mathrm{~Hz}, 2 \mathrm{H}), 3.92(\mathrm{t}, J=6.3 \mathrm{~Hz}, 2 \mathrm{H}), 2.41(\mathrm{t}, J=7.3 \mathrm{~Hz}, 2 \mathrm{H}), 1.92(\mathrm{p}, J=6.8 \mathrm{~Hz}, 2 \mathrm{H}), 1.14(\mathrm{t}, J=7.1 \mathrm{~Hz}, 3 \mathrm{H})$.

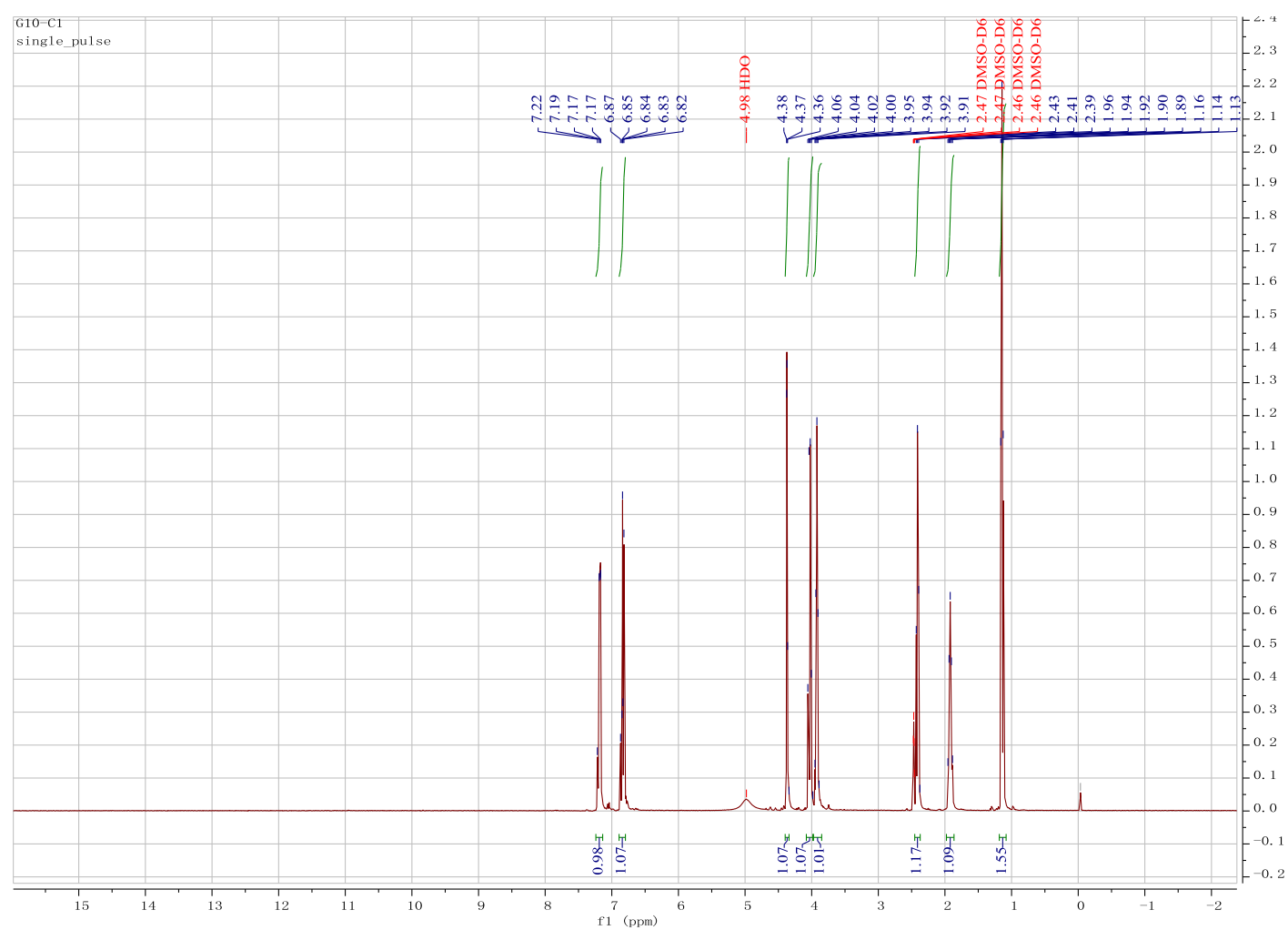


${ }^{13} \mathrm{C}$ NMR (101 MHz, DMSO- $\left.d_{6}\right) \delta 173.09,158.41,157.86,135.11,130.93,129.72,128.44,114.67,114.52,71.29,66.91$, $63.07,60.40,30.66,24.78,14.62$

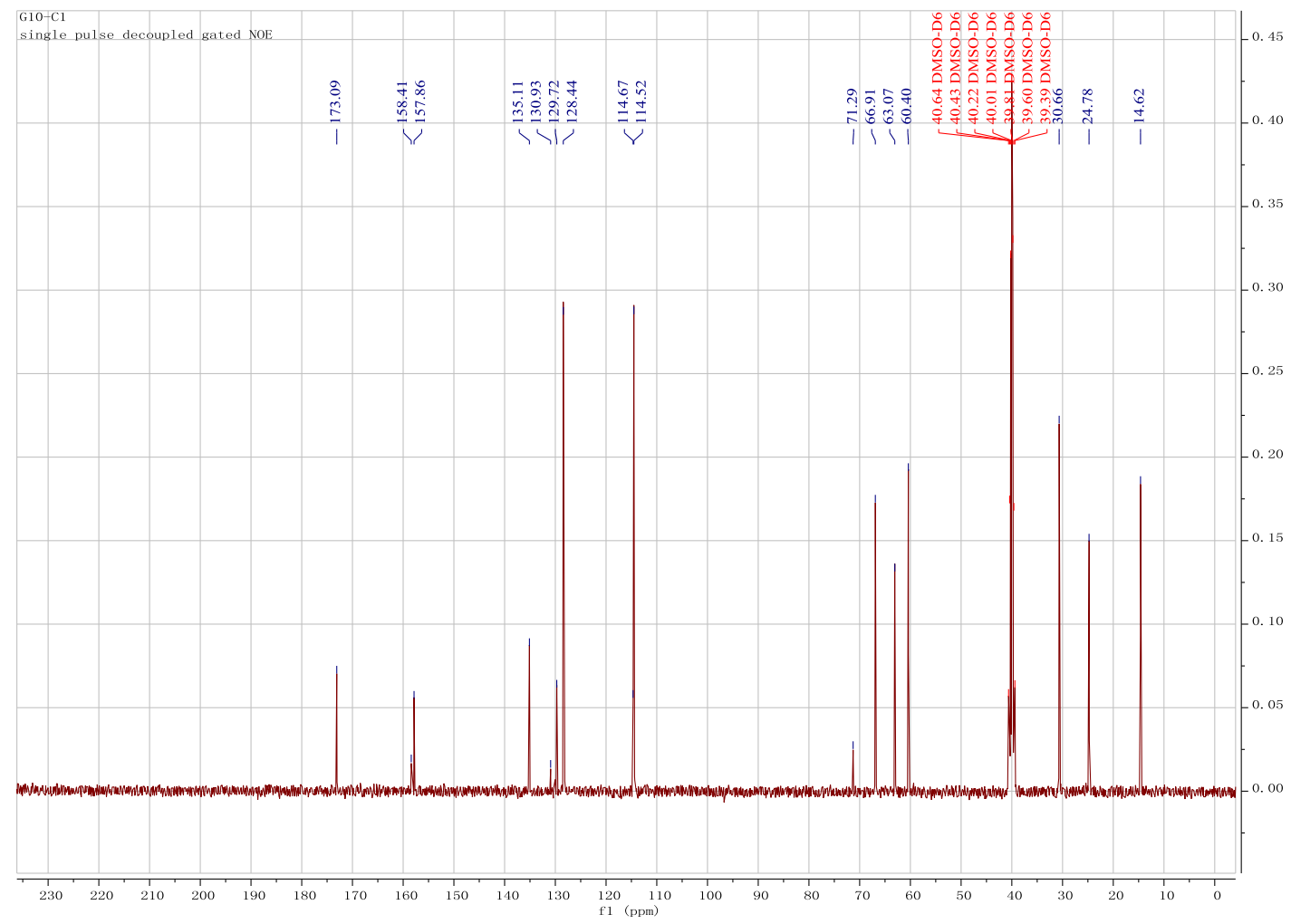

MS calculated for $\mathrm{C}_{13} \mathrm{H}_{18} \mathrm{O}_{4}[\mathrm{M}+\mathrm{Na}]^{+}$: m/z 261.1097; found: 261.1097.

Qualitative Analysis Report

\begin{tabular}{llll} 
& & & \\
Data Filename & $3254 . d$ & Sample Name & G10-C1 \\
Instrument Name & TOF G6230A & Acquired Time & $2019-05-06$ \\
Acq Method & YCL.M & Acquired SW & 6200 series TOF/6500 series \\
IRM Calibration Status & Success & & \\
User Chormatograms & & & \\
\hline
\end{tabular}

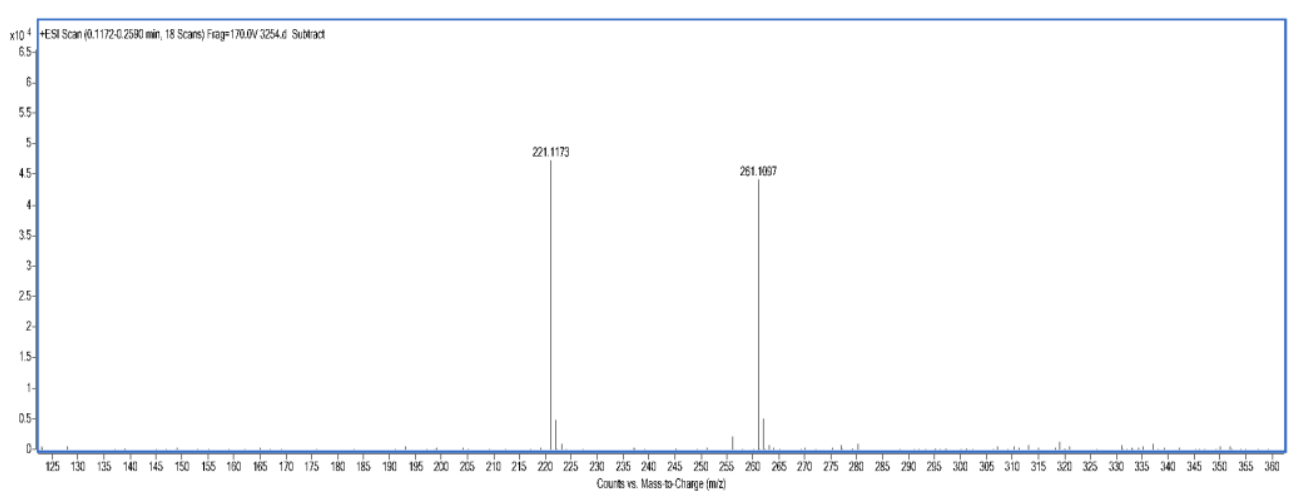


${ }^{1}$ H NMR (400 MHz, DMSO- $\left.d_{6}\right) \delta 7.25-7.16(\mathrm{~m}, 2 \mathrm{H}), 6.89-6.81(\mathrm{~m}, 2 \mathrm{H}), 4.63-4.58(\mathrm{~m}, 1 \mathrm{H}), 4.55(\mathrm{~d}, J=11.6 \mathrm{~Hz}, 1 \mathrm{H})$, $4.31(\mathrm{~d}, J=11.6 \mathrm{~Hz}, 1 \mathrm{H}), 4.03(\mathrm{q}, J=7.2 \mathrm{~Hz}, 2 \mathrm{H}), 3.93(\mathrm{t}, J=6.4 \mathrm{~Hz}, 2 \mathrm{H}), 3.75(\mathrm{~m}, J=11.4,8.2,3.3 \mathrm{~Hz}, 1 \mathrm{H}), 3.43(\mathrm{~m}, J$ $=11.1,4.8,1.4 \mathrm{~Hz}, 1 \mathrm{H}), 2.42(\mathrm{q}, J=7.6 \mathrm{~Hz}, 3 \mathrm{H}), 1.98-1.87(\mathrm{~m}, 2 \mathrm{H}), 1.78-1.53(\mathrm{~m}, 2 \mathrm{H}), 1.52-1.35(\mathrm{~m}, 4 \mathrm{H}), 1.14(\mathrm{t}, J$ $=7.1 \mathrm{~Hz}, 2 \mathrm{H})$.

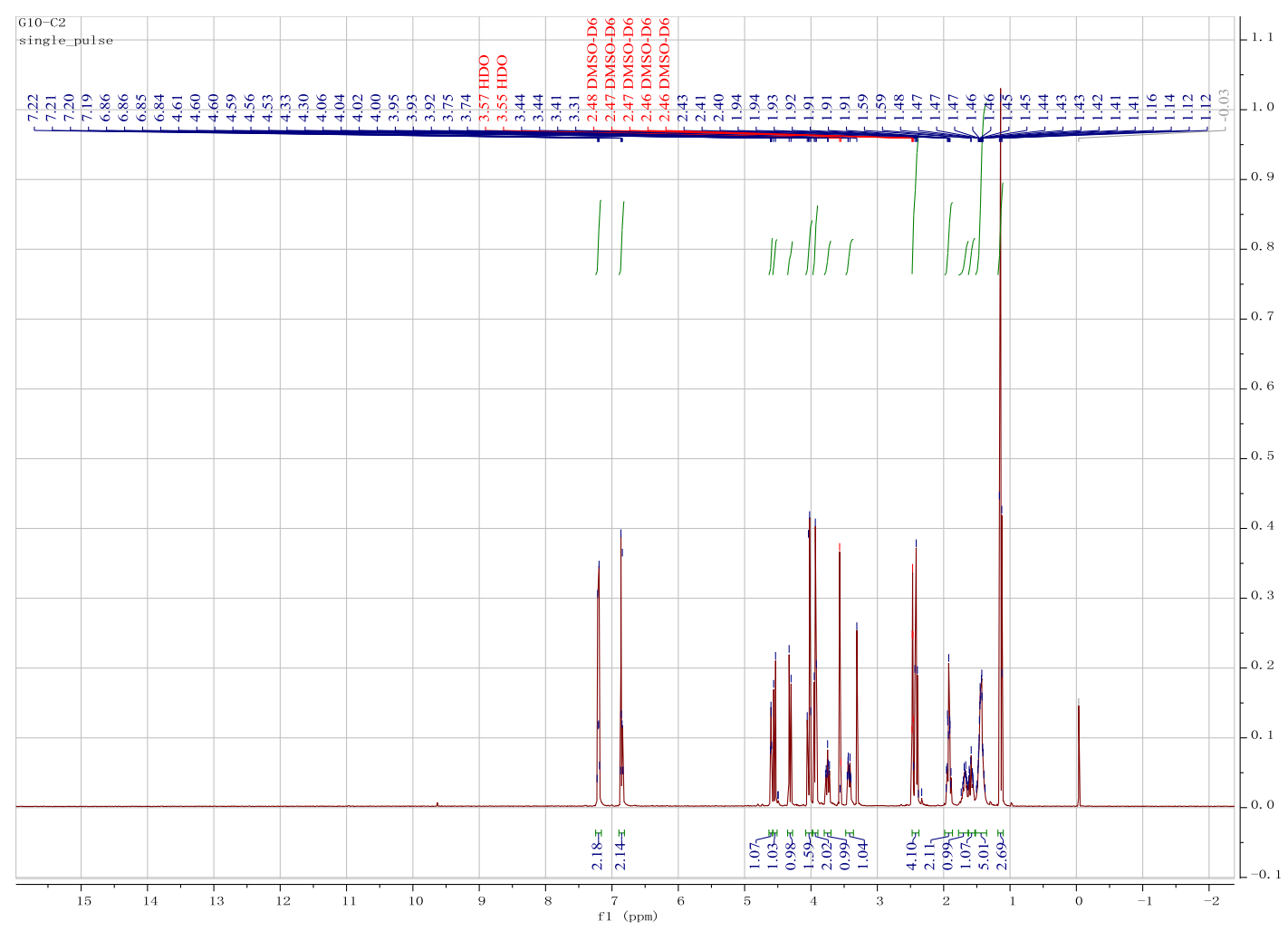


${ }^{13}$ C NMR (101 MHz, DMSO- $\left.d_{6}\right) \delta 173.09,158.39,130.74,129.84,114.68,97.49,68.24,66.94,61.78,60.40,30.72,30.66$, $30.44,25.57,24.74,19.61,14.64$

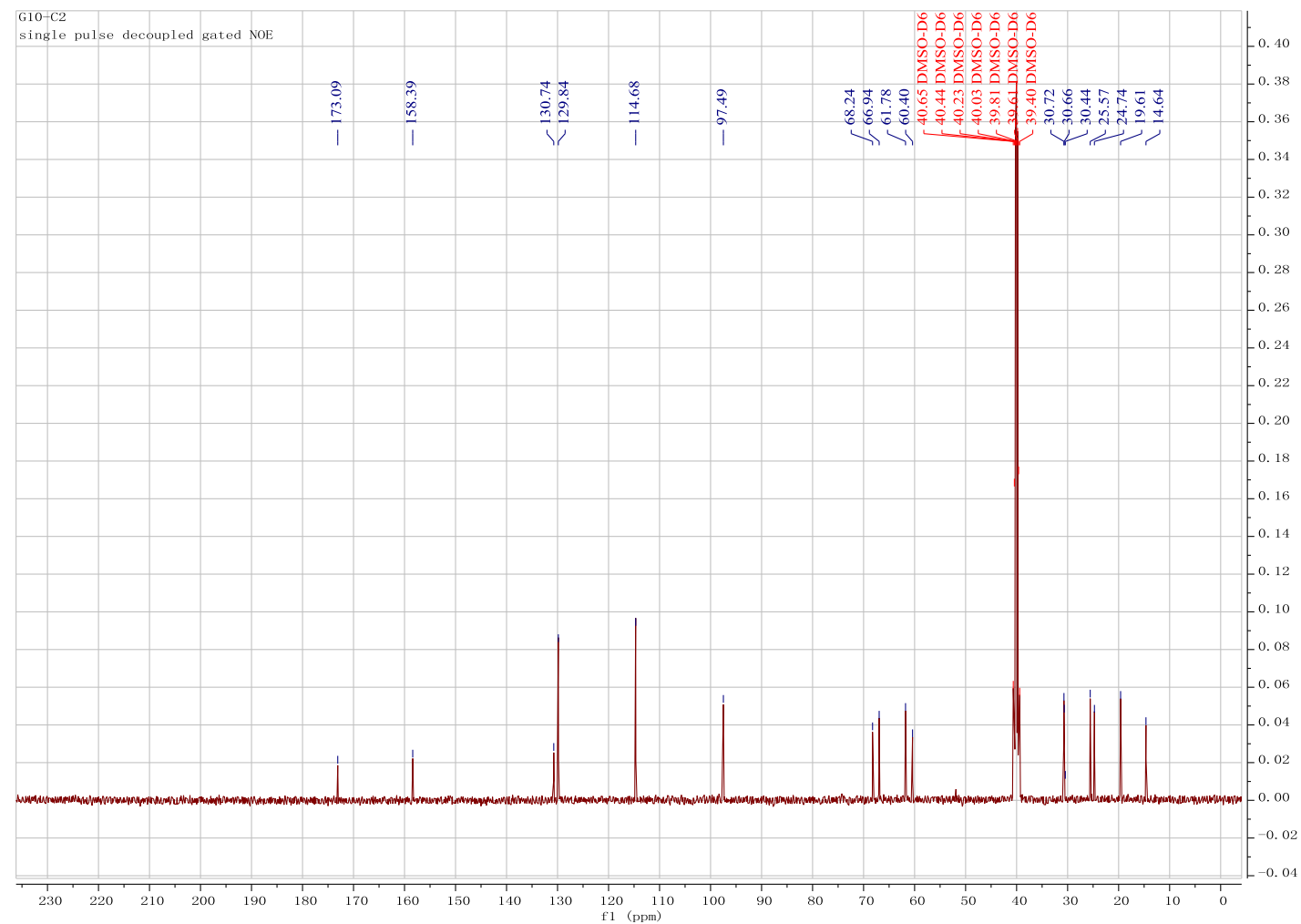

MS calculated for $\mathrm{C}_{18} \mathrm{H}_{26} \mathrm{O}_{5}[\mathrm{M}+\mathrm{Na}]^{+}: \mathrm{m} / \mathrm{z}$ 345.1672; found: 345.1673 .

Qualitative Analysis Report

\begin{tabular}{llll}
\hline & & & \\
Data Filename & 3255.d & Sample Name & G10-C2 \\
Instrument Name & TOF G6230A & Acquired Time & 2019-05-06 \\
Acq Method & YCL.M & Acquired SW & 6200 series TOF/6500 series \\
IRM Calibration Status & Success & & \\
User Chormatograms & & & \\
\hline
\end{tabular}

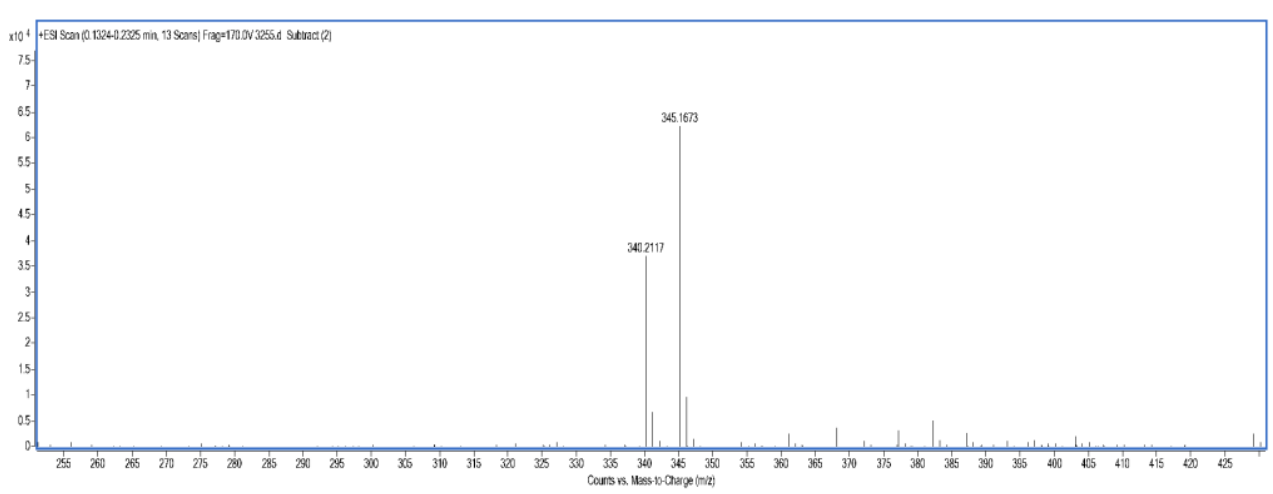




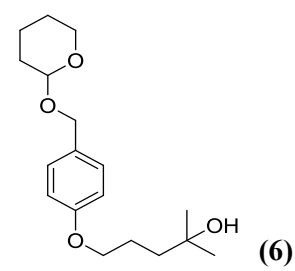

${ }^{1}$ H NMR $\left(400 \mathrm{MHz}, \mathrm{DMSO}-d_{6}\right) \delta 7.24-7.16(\mathrm{~m}, 2 \mathrm{H}), 6.89-6.81(\mathrm{~m}, 2 \mathrm{H}), 4.60(\mathrm{t}, J=3.7 \mathrm{~Hz}, 1 \mathrm{H}), 4.55(\mathrm{~d}, J=11.5 \mathrm{~Hz}$, $1 \mathrm{H}), 4.31(\mathrm{~d}, J=11.5 \mathrm{~Hz}, 1 \mathrm{H}), 4.17(\mathrm{~s}, 1 \mathrm{H}), 3.90(\mathrm{t}, J=6.6 \mathrm{~Hz}, 2 \mathrm{H}), 3.75(\mathrm{~m}, J=11.4,8.2,3.3 \mathrm{~Hz}, 1 \mathrm{H}), 3.48-3.38(\mathrm{~m}$, $1 \mathrm{H}), 1.77-1.63(\mathrm{~m}, 3 \mathrm{H}), 1.59(\mathrm{td}, J=9.4,3.0 \mathrm{~Hz}, 1 \mathrm{H}), 1.52-1.36(\mathrm{~m}, 6 \mathrm{H}), 1.06(\mathrm{~s}, 6 \mathrm{H})$.

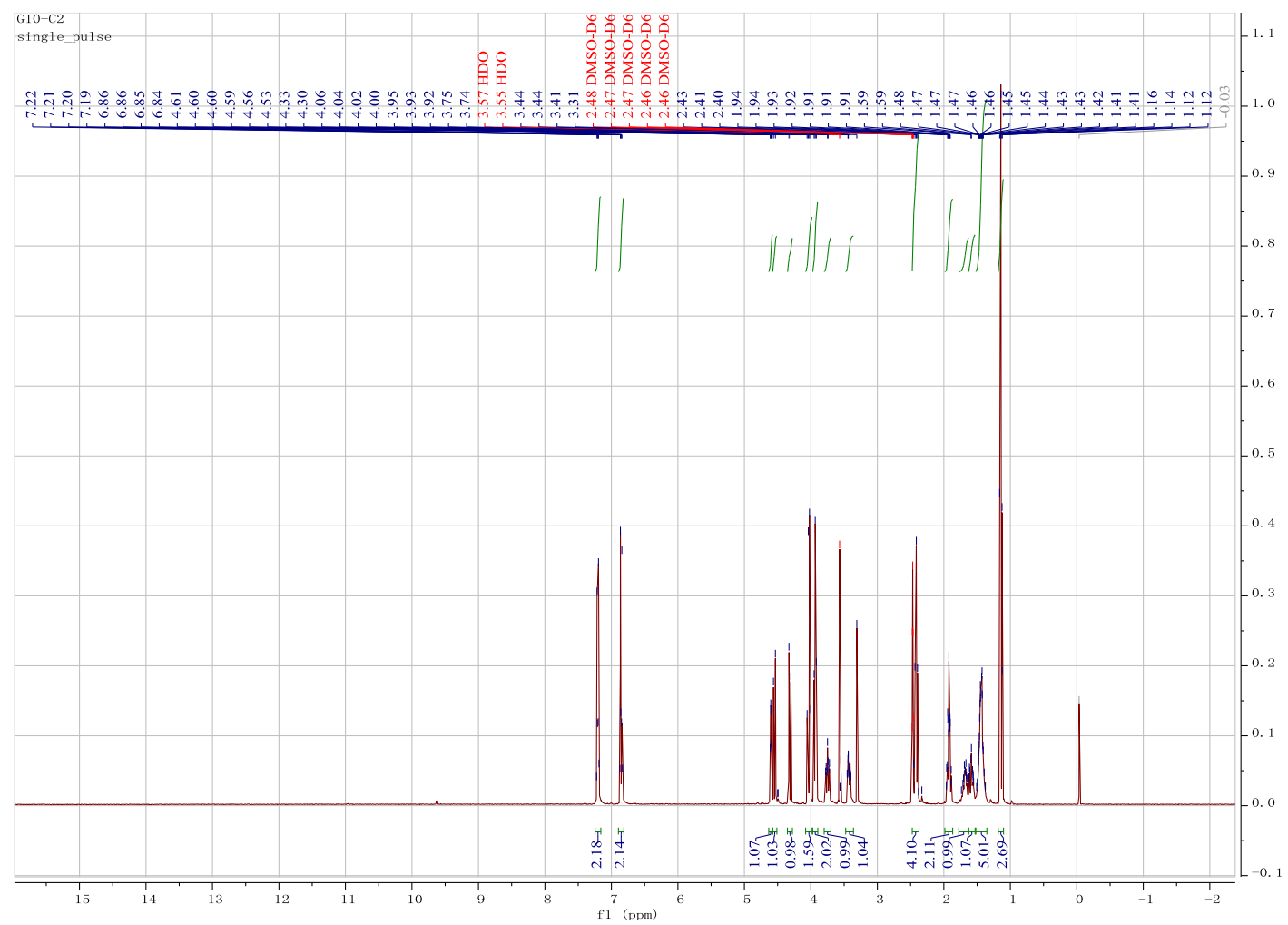


${ }^{13}$ C NMR (101 MHz, DMSO- $\left.d_{6}\right) \delta 158.66,130.51,129.84,114.66,97.49,69.07,68.63,68.27,61.77,30.72,29.86,25.57$, $24.48,19.61$.

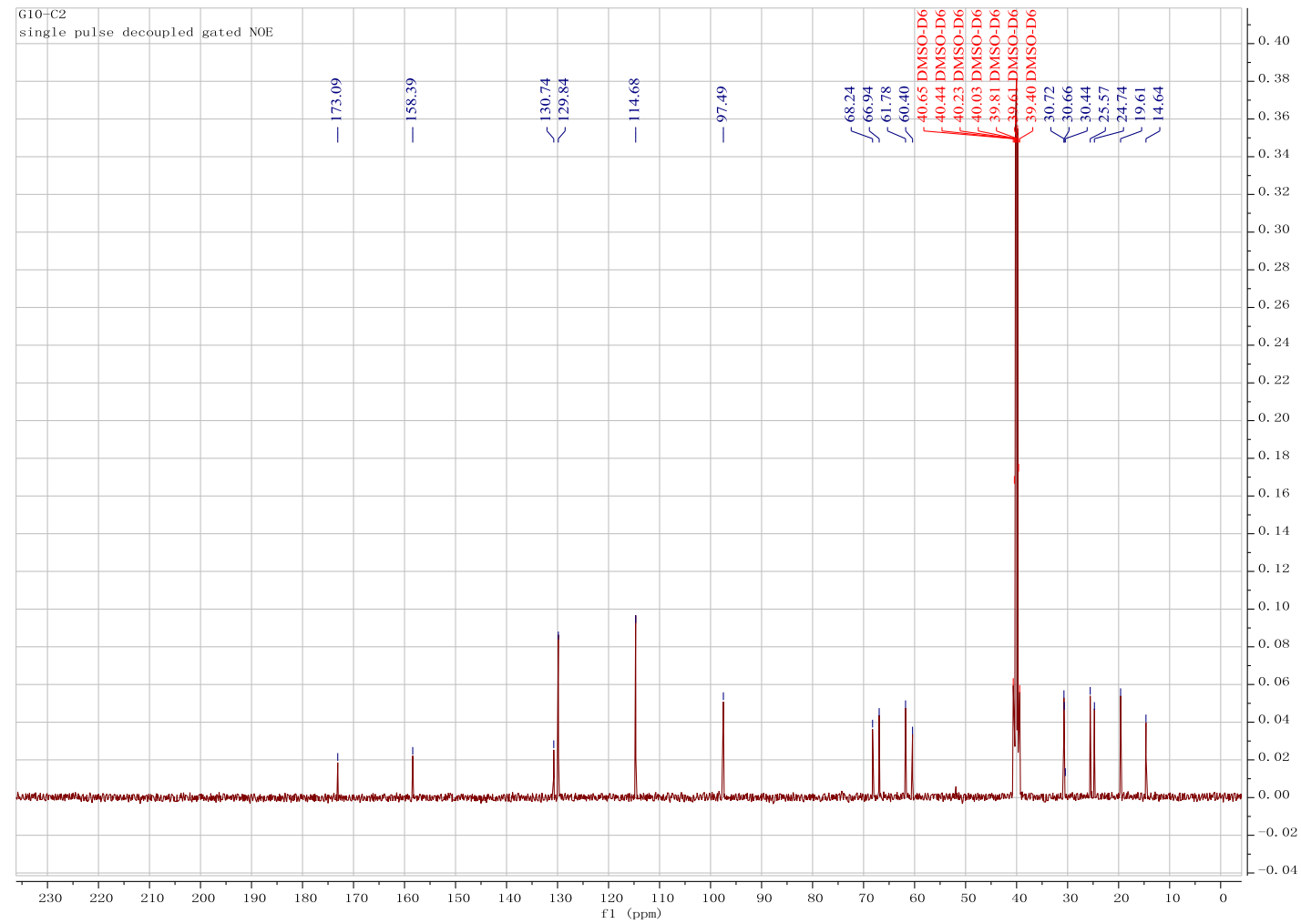

MS calculated for $\mathrm{C}_{18} \mathrm{H}_{28} \mathrm{O}_{4}[\mathrm{M}+\mathrm{Na}]^{+}: \mathrm{m} / \mathrm{z} 331.1880$; found: 331.1883 .

Qualitative Analysis Report

\begin{tabular}{llll}
\hline & & & \\
Data Filename & 3256.d & Sample Name & G10-C4 \\
Instrument Name & TOF G6230A & Acquired Time & 2019-05-06 \\
Acq Method & YCL.M & Acquired SW & 6200 series TOF/6500 series \\
IRM Calibration Status & Success & & \\
User Chormatograms & & & \\
\hline
\end{tabular}

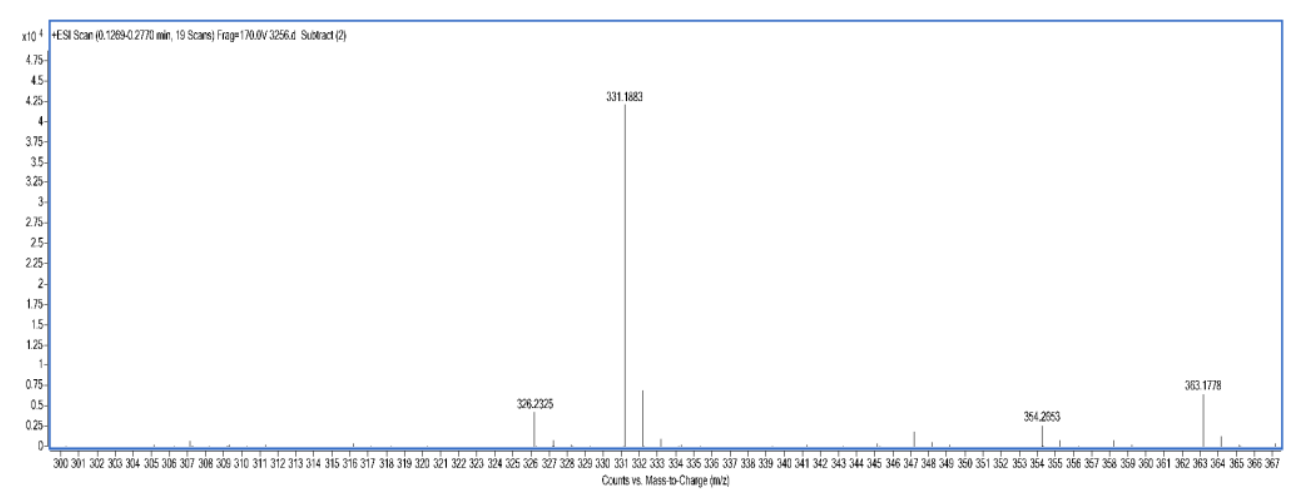


${ }^{1} \mathrm{H}$ NMR (400 MHz, $\left.\mathrm{CDCl}_{3}\right) \delta 8.08(\mathrm{t}, J=1.1 \mathrm{~Hz}, 1 \mathrm{H}), 7.34(\mathrm{q}, J=1.9,1.5 \mathrm{~Hz}, 1 \mathrm{H}), 7.31-7.23(\mathrm{~m}, 2 \mathrm{H}), 7.03(\mathrm{t}, J=1.4$ $\mathrm{Hz}, 1 \mathrm{H}), 6.88-6.80(\mathrm{~m}, 2 \mathrm{H}), 4.74-4.64(\mathrm{~m}, 2 \mathrm{H}), 4.42(\mathrm{~d}, J=11.6 \mathrm{~Hz}, 1 \mathrm{H}), 3.98$ (t, $J=6.1 \mathrm{~Hz}, 2 \mathrm{H}), 3.91$ (ddd, $J=11.5$, 8.1, 3.2 Hz, 1H), $3.58-3.48(\mathrm{~m}, 1 \mathrm{H}), 2.11-2.02(\mathrm{~m}, 2 \mathrm{H}), 1.94-1.79(\mathrm{~m}, 3 \mathrm{H}), 1.79-1.69(\mathrm{~m}, 1 \mathrm{H}), 1.64(\mathrm{~s}, 6 \mathrm{H}), 1.57-$ $1.47(\mathrm{~m}, 2 \mathrm{H})$.

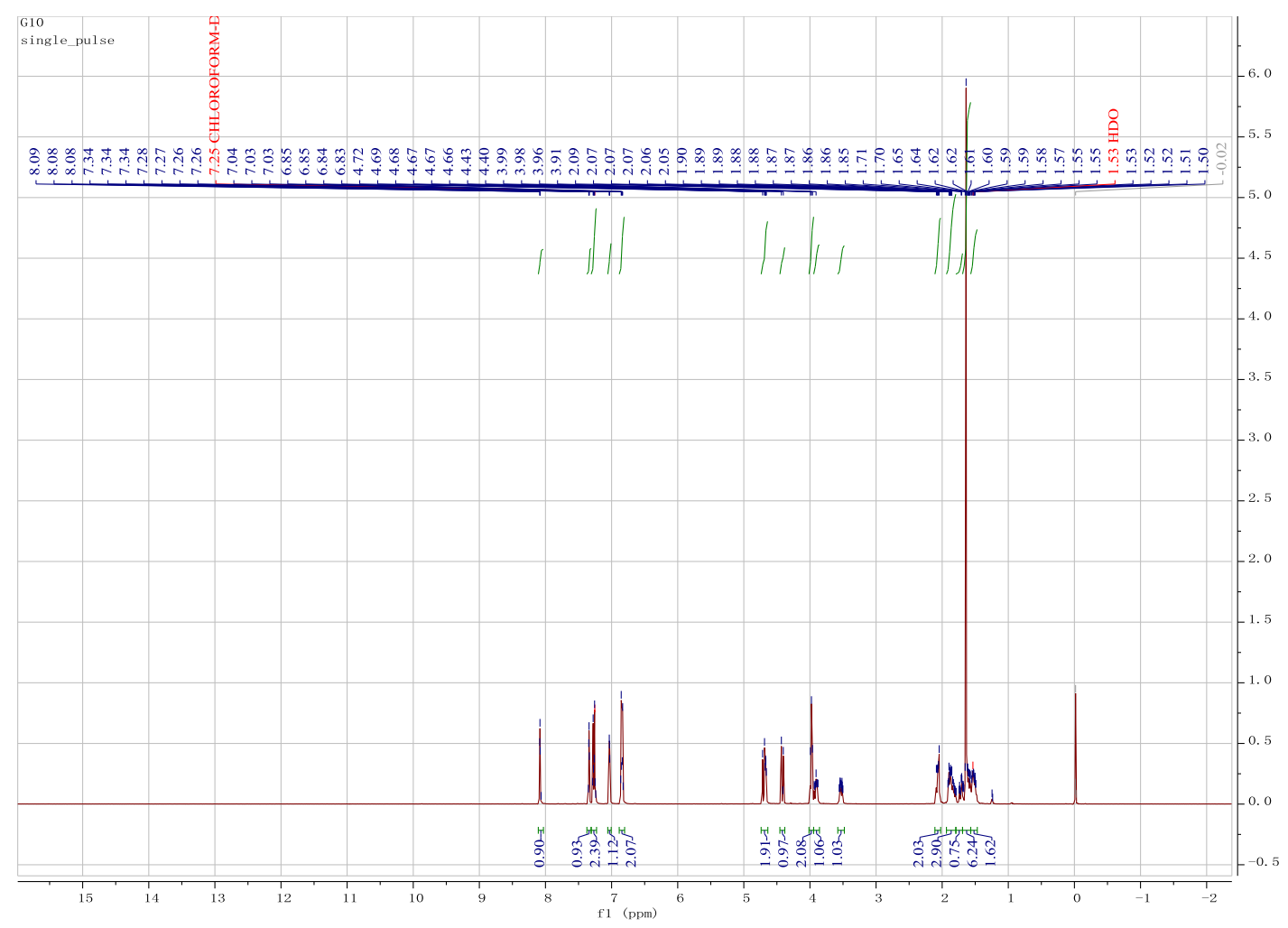


${ }^{13} \mathrm{C}$ NMR $\left(101 \mathrm{MHz}, \mathrm{CDCl}_{3}\right) \delta 158.39,147.07,137.11,130.56,130.38,129.63,117.20,114.39,97.58,87.55,68.56,67.53$, $62.26,37.43,30.68,25.88,25.57,24.05,19.52$

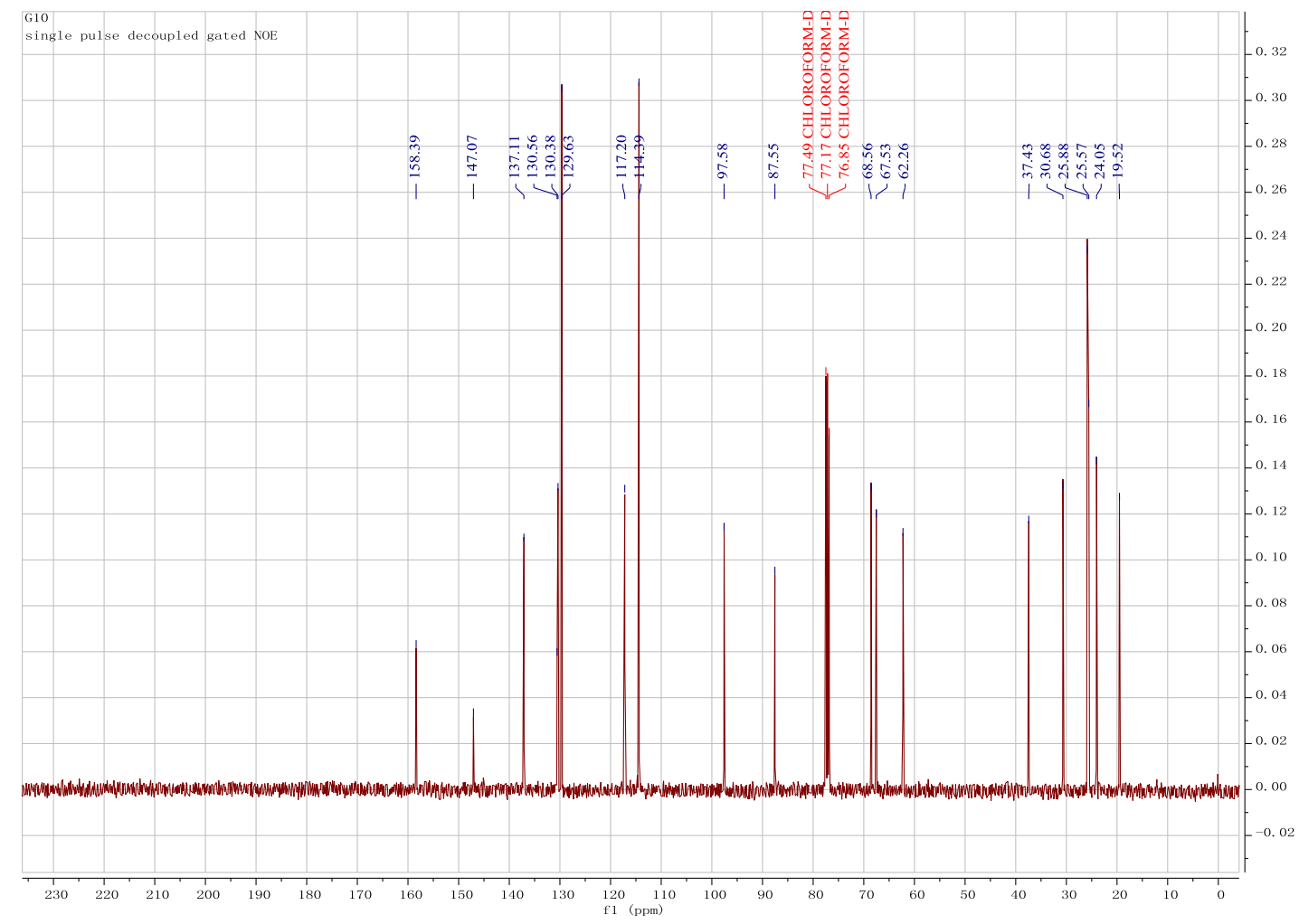

MS calculated for $\mathrm{C}_{22} \mathrm{H}_{30} \mathrm{~N}_{2} \mathrm{O}_{4}[\mathrm{M}+\mathrm{H}]^{+}: \mathrm{m} / \mathrm{z}$ 403.2227; found: 403.2227 .

Qualitative Analysis Report

\begin{tabular}{llll}
\hline & & & \\
Data Filename & 2732.d & Sample Name & G10 \\
Instrument Name & TOF G6230A & Acquired Time & 2019-04.03 \\
Acq Method & YCL.M & Acquired SW & 6200 series TOF/6500 series \\
IRM Calibration Status & Success & & \\
User Chormatograms & & & \\
\hline
\end{tabular}

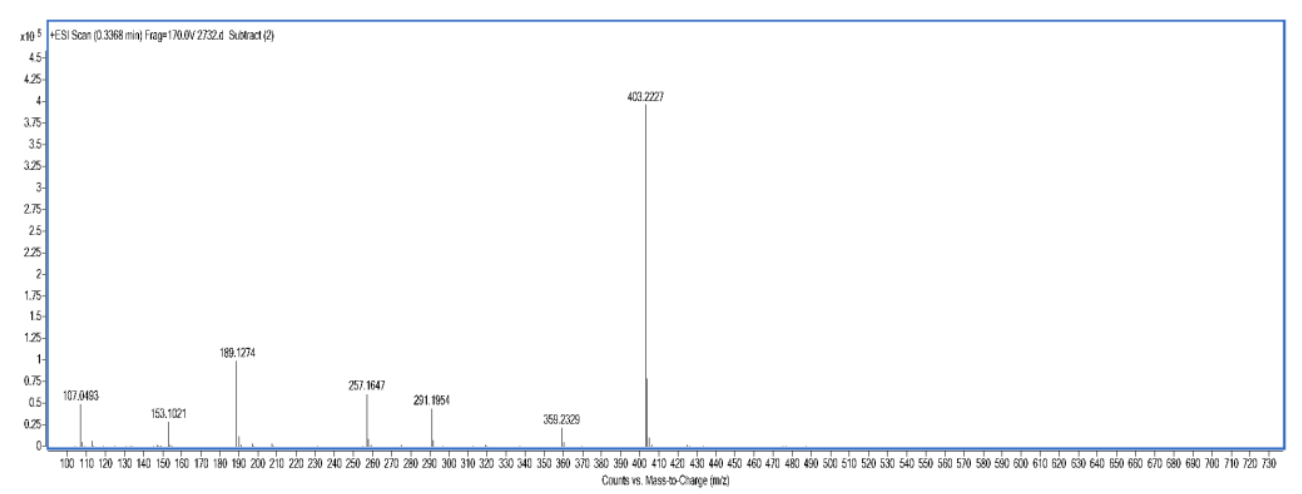




\section{GENERAL PROCEDURE FOR HETERODIMER SYNTHESIS}

\section{a) General procedures for solid-phase reactions and TFA cleavage}

Two peptides were synthesized in $0.200 \mathrm{~g}$ scale $(0.11 \mathrm{mmol}, 0.56 \mathrm{mmol} / \mathrm{g})$. The peptide was synthesized as follows (a): Fmoc deprotection: 20\% piperidine in DMF 15 min; washings: DMF $(3 \times 1 \mathrm{~min}), \mathrm{CH}_{2} \mathrm{Cl}_{2}(3 \times 1 \mathrm{~min})$, and DMF $(3 \times 1$ min); (b): Peptide coupling conditions: HATU (3.8 equiv), Fmoc-amino acid (4 equiv) and DIPEA (8 equiv) in DMF, 1 h; washings: DMF $(3 \times 1 \mathrm{~min})$; the coupling reaction was monitored by the Kaiser test.

Micro-cleavage procedure: Dry resin $(5 \mathrm{mg})$ was treated with TFA/TIS/EDT/m-Cresol/ $\mathrm{H}_{2} \mathrm{O}(90: 2.5: 2.5: 2.5: 2.5, v / v)$ for $1 \mathrm{~h}$ at room temperature with occasionally shaken. The cleavage mixture was filtered and evaporated under vacuum, precipitated with $\mathrm{Et}_{2} \mathrm{O}$, centrifuged and the pellet was dissolved in eluent system for analysis by RP-HPLC.

Side chain protecting groups and peptide were cleaved from the solid support with a solution of TFA/TIS/EDT/mCresol/ $\mathrm{H}_{2} \mathrm{O}(90: 2.5: 2.5: 2.5: 2.5, v / v)$ for $1 \mathrm{~h}$ at room temperature. After cleavage, the resin was removed by filtration, the filtrate was concentrated under a stream of nitrogen and the peptide products were precipitated in ice-cold $\mathrm{Et}_{2} \mathrm{O}$ and washed by centrifugation three times. The peptides were analyzed and purified by RP-HPLC using water and acetonitrile with $0.1 \%$ TFA gradients. The final products were characterized by RP-HPLC and Q-FT-ICR-MS and/or ESI-MS.

b) preparation of onium salt $(8)$

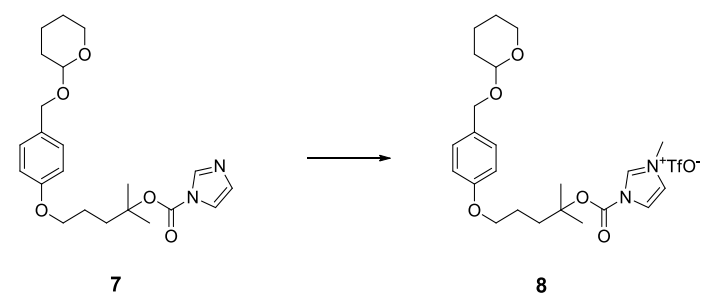

To a solution of $0.44 \mathrm{~g}(1.1 \mathrm{mmol})(7)$ dissolved in $5 \mathrm{~mL}$ anhydrous $\mathrm{CH}_{2} \mathrm{Cl}_{2}$ was cooled to $0 \mathrm{C}^{\circ}, 113 \mu \mathrm{L}(1.0 \mathrm{mmol})$ TfOMe was added via pipette in one portion, the reaction was capped and allowed to stirred in r.t for $5 \mathrm{~min}$, the solution was used directly without purification.

c) Coupling of linker and release of the hydroxy group

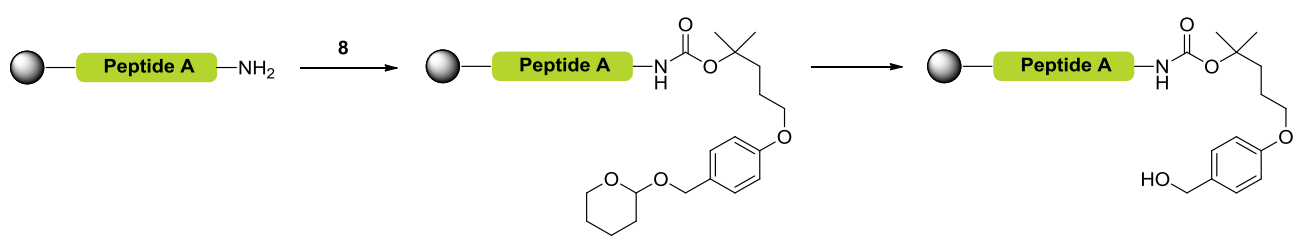

A solution of (8) (1.0 mmol), DIPEA (2.0 mmol) in $\mathrm{CH}_{2} \mathrm{Cl}_{2}$ was added into the peptide-resin $(0.11 \mathrm{mmol})$ and allowed to react for $6 \mathrm{~h} \times 2$ at room temperature. The resulting resin was then capped with $\mathrm{Ac}_{2} \mathrm{O}$ - pyridine-DMF solution $(1: 1: 3, v / v)$ for $1 \mathrm{~h}$, then washed with DMF $(3 \times 1 \mathrm{~min}), \mathrm{CH}_{2} \mathrm{Cl}_{2}(3 \times 1 \mathrm{~min})$. A solution of TsOH $(5 \mathrm{mg} / \mathrm{mL})$ in $\mathrm{CH}_{2} \mathrm{Cl}_{2}-\mathrm{MeOH}(9: 1, v / v)$ was added $(10 \mathrm{~mL}$ for 1 -gram resin) and allowed to react for $60 \mathrm{~min} \times 2$. The solution was filtered and the resin was washed with $\mathrm{DMF}(3 \times 1 \mathrm{~min}), \mathrm{CH}_{2} \mathrm{Cl}_{2}(3 \times 1 \mathrm{~min})$, and $\mathrm{DMF}(3 \times 1 \mathrm{~min})$.

d) Coupling of $\mathrm{C}$-terminal amino acid of the second peptide

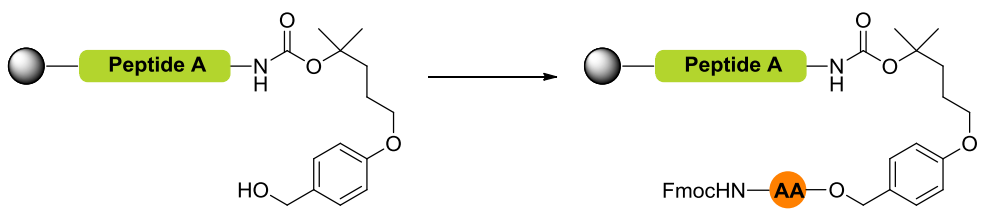

A solution of Fmoc-amino acid (10 equiv), DIC (5 equiv), DMAP (0.2 equiv) in $\mathrm{CH}_{2} \mathrm{Cl}_{2}-\mathrm{DMF}(9: 1, v / v)$ was added onto the resin and allowed to react for $8 \mathrm{~h}$. The solution was filtered and the resin was washed with DMF $(3 \times 1 \mathrm{~min})$, $\mathrm{CH}_{2} \mathrm{Cl}_{2}(3 \times 1 \mathrm{~min})$, and DMF $(3 \times 1 \mathrm{~min})$. 
e) Preparation of peptide (I)
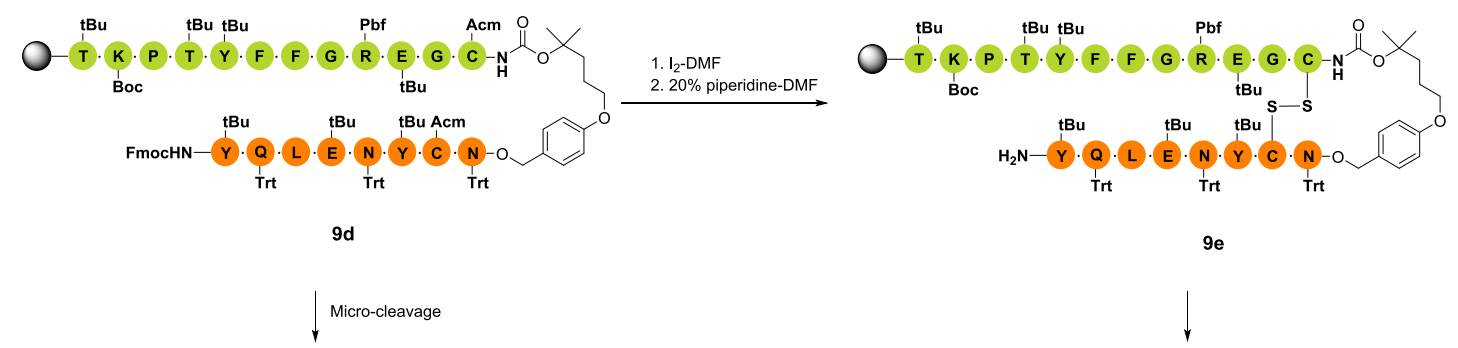

A(SAcm)

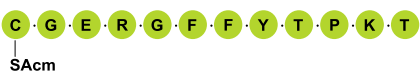

SAcm

B(SAcm)

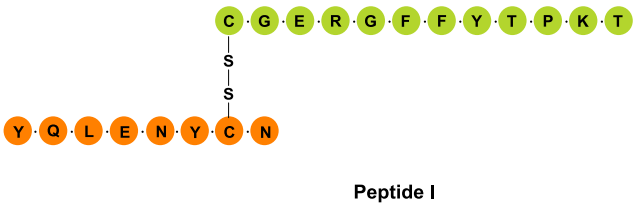

Peptide I was synthesized from $0.200 \mathrm{~g}$ of Wang resin $(0.11 \mathrm{mmol}, 0.56 \mathrm{mmol} / \mathrm{g})$. After the assembly was completed, $150 \mathrm{mg} \mathrm{I}_{2}(0.6 \mathrm{mmol})$ dissolved in $6 \mathrm{~mL}$ DMF was added to the resin-bound peptide and react for $15 \mathrm{~min}$. The solution was filtered and the resin was washed with ascorbic acid solution to remove the excess I2. The resin was then washed with DMF until the filtrate is colorless, then the resin was treated with $20 \%$ piperidine-DMF solution for 15 min to remove the Fmoc group. The resulting resin was washed with DMF $(3 \times 1 \mathrm{~min}), \mathrm{CH}_{2} \mathrm{Cl}_{2}(3 \times 1 \mathrm{~min})$. The peptide was then cleaved from the resin by treatment with TFA/TIS/EDT/ $m$-Cresol/ $\mathrm{H}_{2} \mathrm{O}(90: 2.5: 2.5: 2.5: 2.5, v / v)$ for $1 \mathrm{~h}$ at room temperature. After cleavage, the resin was removed by filtration, the filtrate was concentrated under a stream of nitrogen and the peptide products were precipitated in ice-cold $\mathrm{Et}_{2} \mathrm{O}$ and washed by centrifugation three times. The crude peptide was dried in $\mathrm{Ar}$ gas, gave 266 mg heterodimer peptide (I). The crude peptide was analyzed and purified by RP-HPLC using water and acetonitrile with $0.1 \%$ TFA gradients $(10 \% \sim 40 \%, 30 \mathrm{~min}, 220 \mathrm{~nm})$, gave pure peptide (I) $76.2 \mathrm{mg}$. The overall yield is $27.8 \%$ based upon resin substitution. The final products were characterized by RP-HPLC and Q-FT-ICR-MS. MS calculated for $\mathrm{C}_{109} \mathrm{H}_{153} \mathrm{~N}_{27} \mathrm{O}_{34} \mathrm{~S}_{2}[\mathrm{M}+\mathrm{H}]^{+}$: m/z 2449.059; found: 2449.072 . 

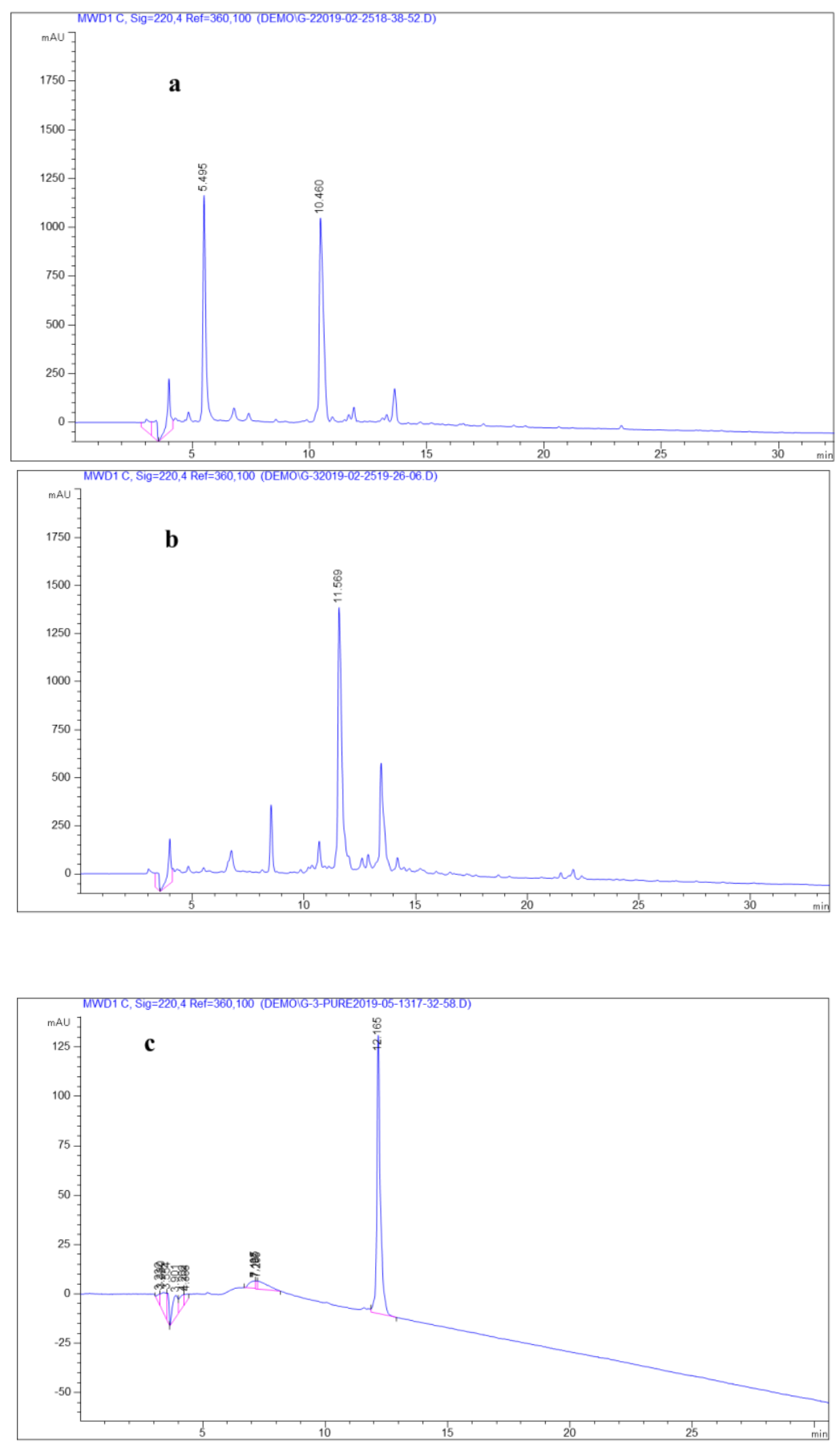

Figure 1. RP-HPLC chromatograms data. a) mixture of I (A) and I (B); b) crude peptide I; c) b) pure peptide $\mathbf{I}$. $\mathrm{CH}_{3} \mathrm{CN}-\mathrm{H}_{2} \mathrm{O}(0.1 \%$ TFA) as the eluent system $(1 \mathrm{~mL} / \mathrm{min}, 20 \%-50 \%, 30 \mathrm{~min})$ 
Q-FT-ICR-MS of peptide I (11.6 min in Figure 1b), MS calculated for $\mathrm{C}_{109} \mathrm{H}_{153} \mathrm{~N}_{27} \mathrm{O}_{34} \mathrm{~S}_{2}[\mathrm{M}+\mathrm{H}]^{+}: \mathrm{m} / \mathrm{z} 2449.059$; found: 2449.072 .

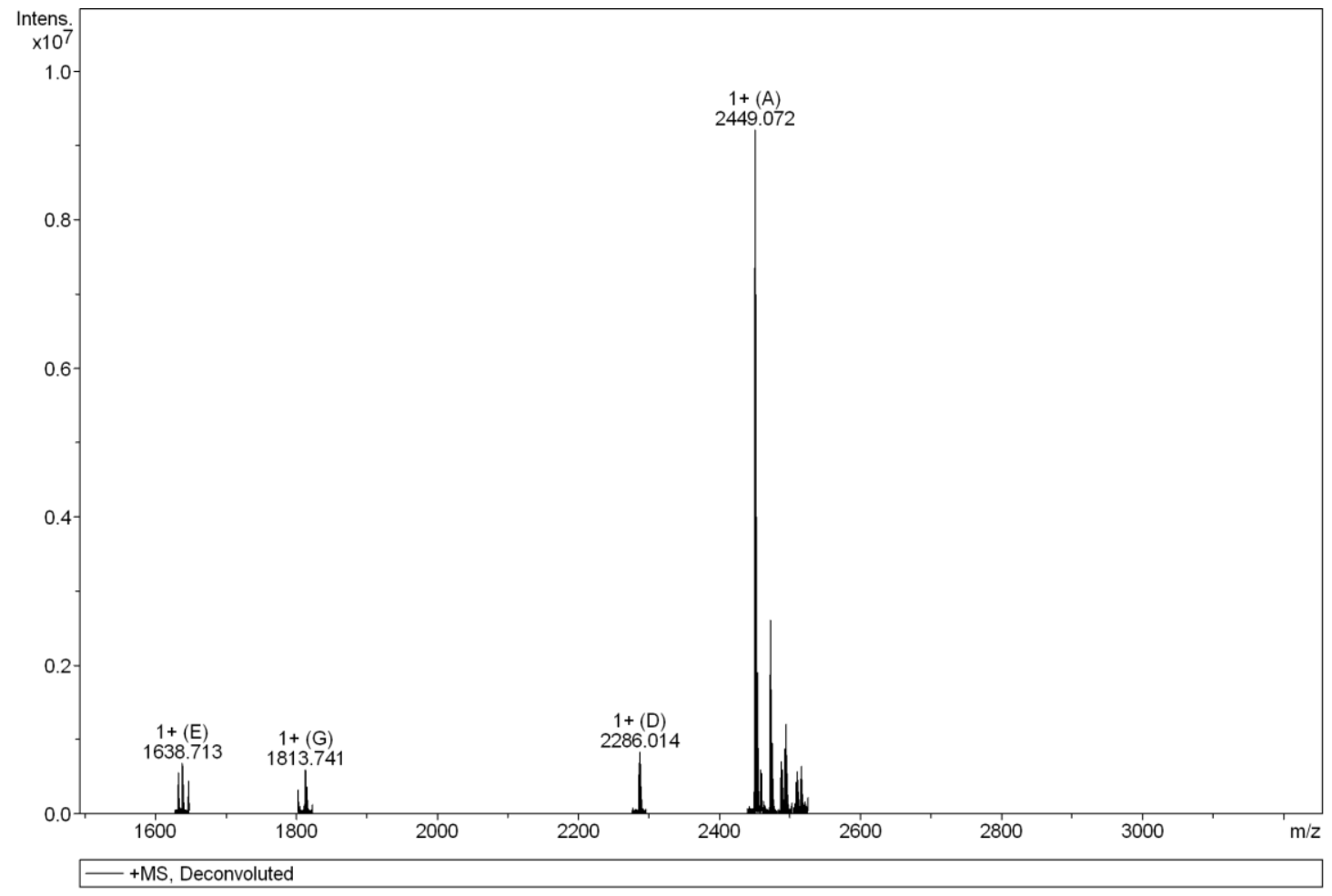

Q-FT-ICR-MS of by-product B-B (8.5min in Figure 1b), MS calculated for $\mathrm{C}_{90} \mathrm{H}_{124} \mathrm{~N}_{22} \mathrm{O}_{32} \mathrm{~S}_{2}[\mathrm{M}+\mathrm{H}]^{+}: \mathrm{m} / \mathrm{z} 2089.827$; found: 2089.826 .

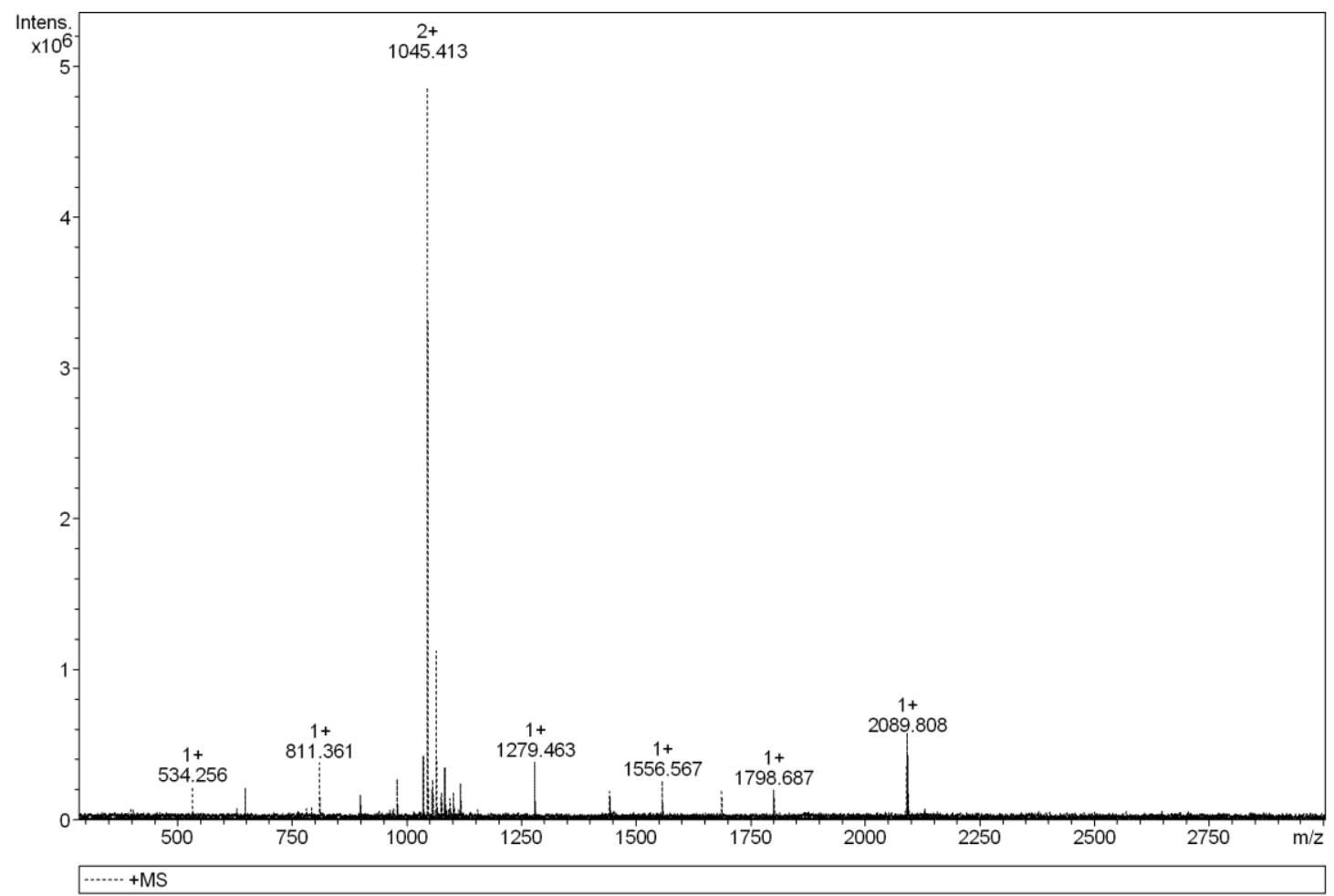


Q-FT-ICR-MS of by-product A-A (13.5min in Figure 1b), MS calculated for $\mathrm{C}_{128} \mathrm{H}_{182} \mathrm{~N}_{32} \mathrm{O}_{36} \mathrm{~S}_{2}[\mathrm{M}+\mathrm{H}]^{+}: \mathrm{m} / \mathrm{z}$ 2808.291; found: 2808.288 .

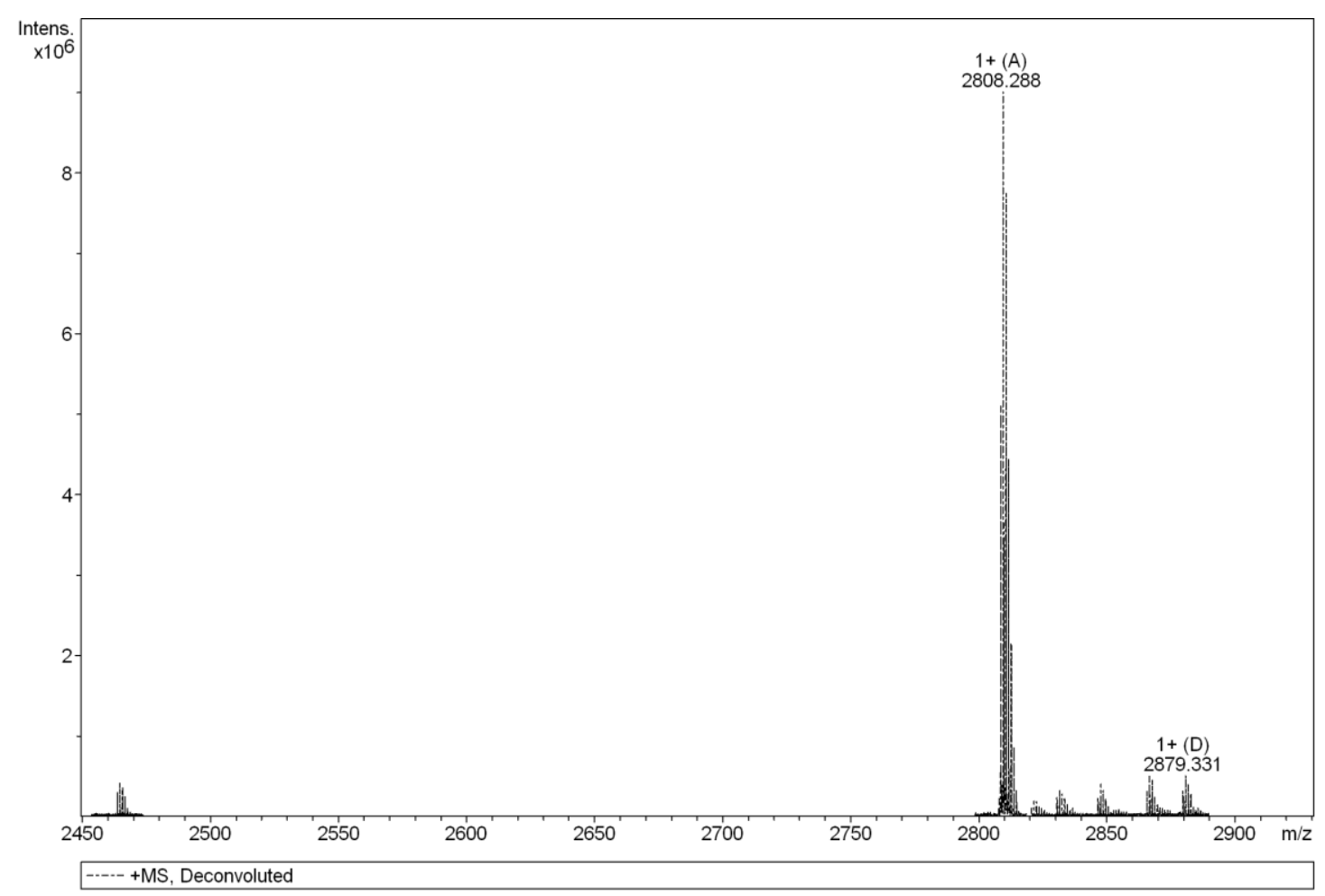




\section{f) Preparation of peptide (II)}

Formation of the first disulfide bonds on-resin

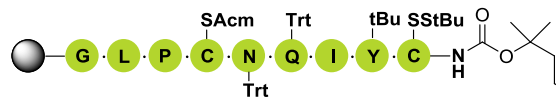

\section{SMmt} tBu tBu tBu tBu Boc Trt

$11 \mathrm{a}$

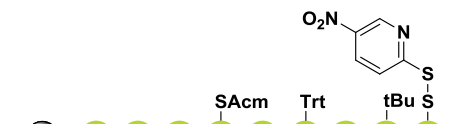

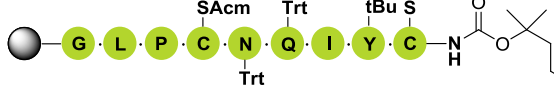

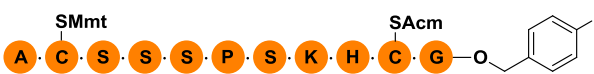

tBu tBu tBu tBu Boc Trt

$11 \mathrm{c}$

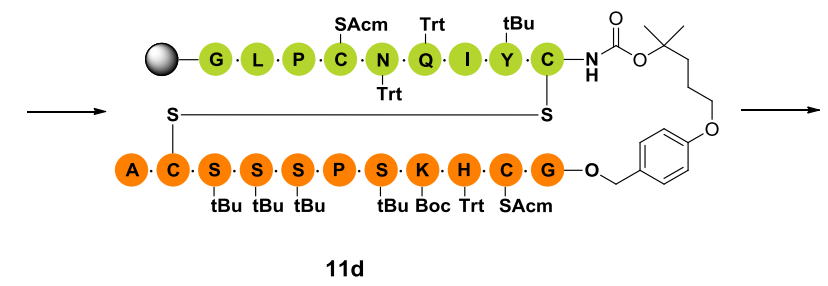

C . Y ( I) Q Q. N . C . P . L . G

$$
\begin{aligned}
& 1 \\
& \mathbf{s} \\
& \mathbf{s} \\
& 1
\end{aligned}
$$

A. C.S.S.S.P.S.K.H.C.G

$11 \mathrm{e}$
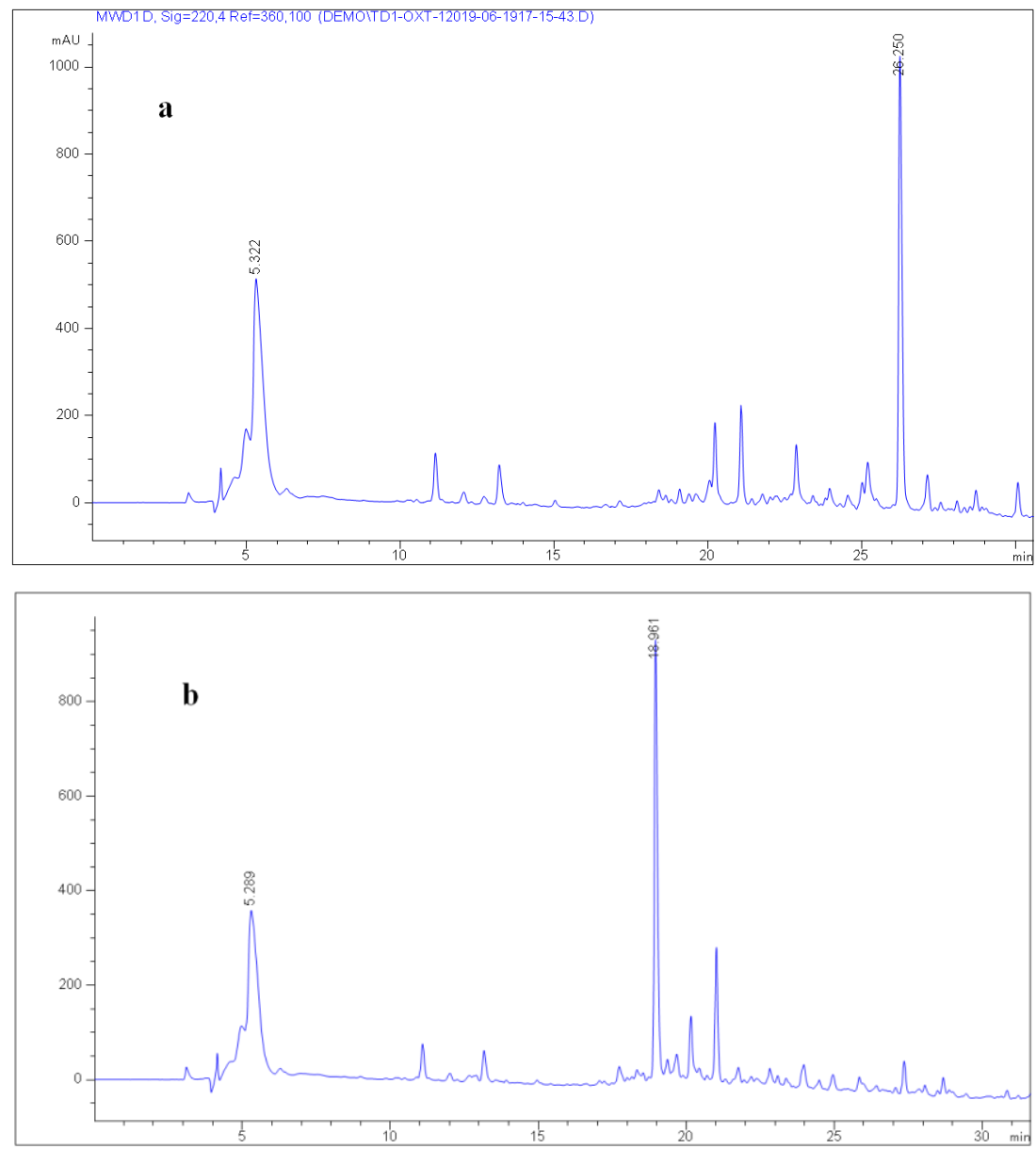

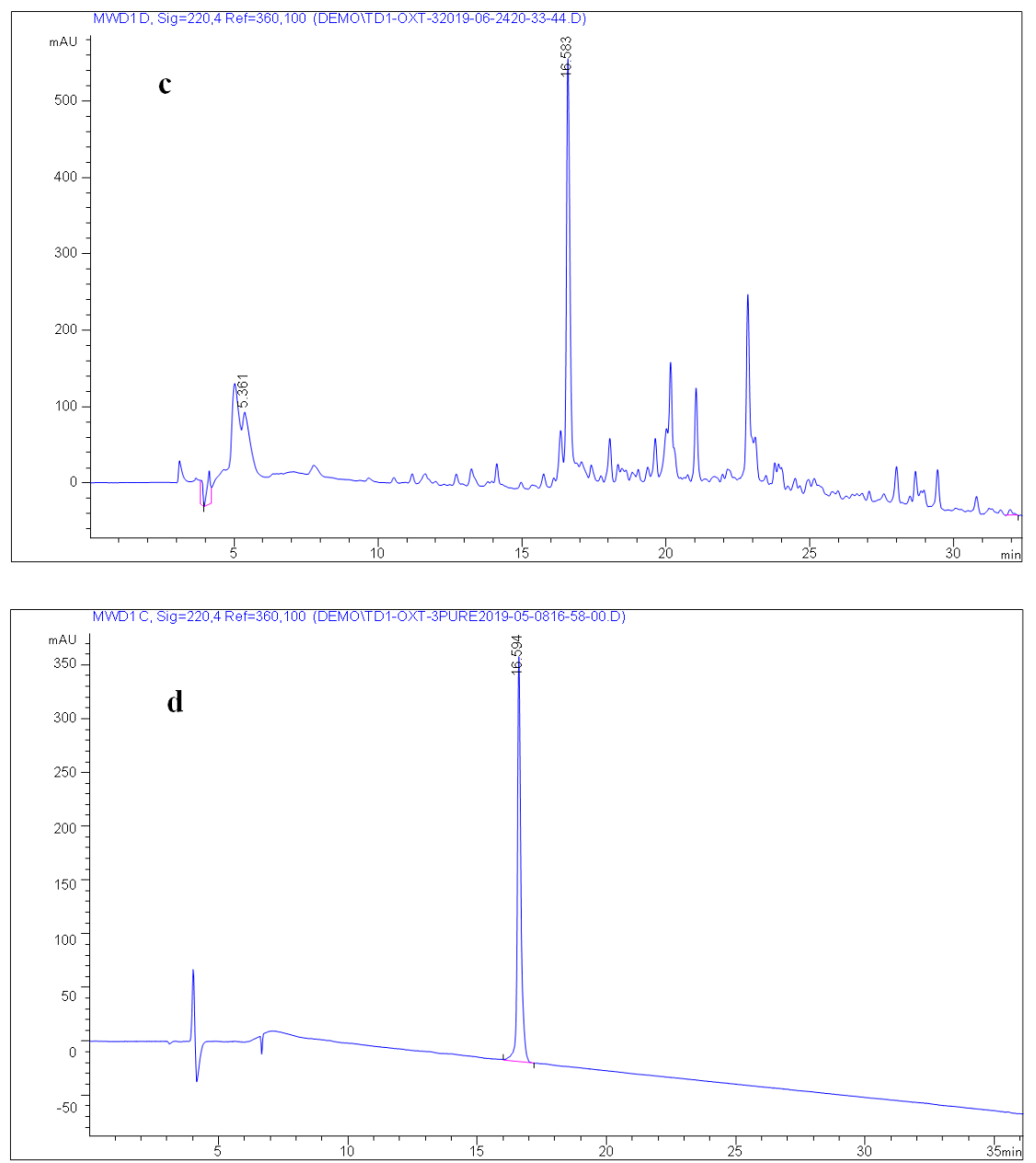

Figure 2. RP-HPLC chromatograms data. a) micro-cleavage of peptide-resin 11a and analysis; b) micro-cleavage of peptide-resin 11b and analysis; c) crude 11e; d) purified 11e. $\mathrm{CH}_{3} \mathrm{CN}-\mathrm{H}_{2} \mathrm{O}(0.1 \%$ TFA) as the eluent system (1 mL/min, $10 \%-40 \%, 30 \mathrm{~min})$

Peptide II was synthesized from $0.200 \mathrm{~g}$ of Wang resin $(0.11 \mathrm{mmol}, 0.56 \mathrm{mmol} / \mathrm{g})$. After the assembly was completed, 8mL 20\% BME-DMF solution contains 0.1M DIPEA was added to the resin-bound peptide and react for 10h. Microcleavage and RP-HPLC analysis indicated the removal of StBu was completed. The resin was washed with DMF $(3 \times 1$ min) and $\mathrm{CH}_{2} \mathrm{Cl}_{2}(3 \times 1 \mathrm{~min})$. The resin was then mixed with $\mathrm{CH}_{2} \mathrm{Cl}_{2}(6 \mathrm{~mL})$ containing DNTP $(1.20 \mathrm{mmol}, 370 \mathrm{mg})$. The mixture was gently agitated for $1 \mathrm{~h}$. The solution was removed and resin was washed with DMF $(6 \times 1 \mathrm{~min})$ and $\mathrm{CH}_{2} \mathrm{Cl}_{2}$ $(6 \times 1 \mathrm{~min})$ and then treated with $1 \% \mathrm{TFA}, 5 \%$ TIS in $\mathrm{CH}_{2} \mathrm{Cl}_{2}(6 \times 3 \mathrm{~min}, 6 \mathrm{~mL}$ each). The resulting resin was washed with $\mathrm{CH}_{2} \mathrm{Cl}_{2}(3 \times 1 \mathrm{~min})$ and DMF $(3 \times 1 \mathrm{~min})$, then further agitated in DMF $(8 \mathrm{~mL})$ for $2 \mathrm{~h}$ at room temperature. The solution was removed and washed with DMF $(3 \times 1 \mathrm{~min})$ and $\mathrm{CH}_{2} \mathrm{Cl}_{2}(3 \times 1 \mathrm{~min})$. The crude peptide was cleaved from the solid support by treatment with TFA/TIS/EDT/m-Cresol/ $\mathrm{H}_{2} \mathrm{O}(90: 2.5: 2.5: 2.5: 2.5, v / v)$ for $1 \mathrm{~h}$. After cleavage, the resin was removed by filtration, the filtrate was concentrated under a stream of nitrogen and the peptide products were precipitated in ice-cold $\mathrm{Et}_{2} \mathrm{O}$ and washed by centrifugation three times. The crude peptide was dried in $\mathrm{Ar}$ gas, dissolved in $10 \%$ aqueous acetonitrile containing $0.1 \%$ TFA for preparative RP-HPLC purification. $46.2 \mathrm{mg}$ of 11e was obtained after lyophilization of the pooled fractions with a yield of $18.6 \%$ based upon resin substitution. The products were characterized by RP-HPLC and Q-FT-ICR-MS. MS calculated for $\mathrm{C}_{89} \mathrm{H}_{141} \mathrm{~N}_{27} \mathrm{O}_{31} \mathrm{~S}_{4}[\mathrm{M}+\mathrm{H}]^{+}$: $\mathrm{m} / \mathrm{z} 2212.924$; found: 2212.886 . 
Formation of the second disulfide bonds in solution

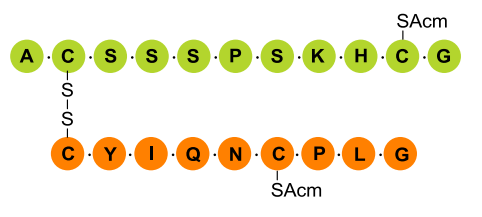

$11 \mathrm{e}$

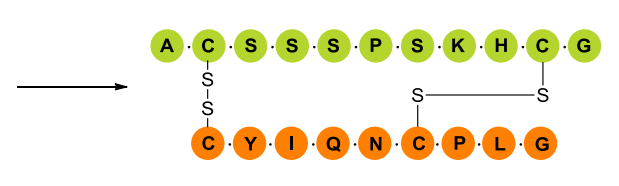

peptide II

To a solution of $4.5 \mathrm{mg} 11 \mathrm{e}$ dissolved in $1.5 \mathrm{~mL} \mathrm{HOAc}-\mathrm{H}_{2} \mathrm{O}(4: 1, v / v)$ was added $1 \mathrm{~mL}$ iodine solution $(20 \mathrm{mM}$ in $\mathrm{HOAc}$ ) in one portion. The resulting solution was stirred in room temperature in darkness. The progress of the reaction was monitored by RP-HPLC. To facile the HPLC detective, $5 \mu \mathrm{L}$ reaction solution was quenched by $10 \mu \mathrm{L} 20 \mathrm{mM}$ ascorbic acid solution and diluted by adding $50 \mu \mathrm{L}$ water. The resulting solution was analyzed by RP-HPLC directly. On complete oxidation, the reaction was quenched by adding $20 \mathrm{mM}$ ascorbic acid solution until the color was disappears. The solution was diluted with water and lyophilized, the residue was purified by preparative RP-HPLC. $3.8 \mathrm{mg}$ of peptide II was obtained after lyophilization of the pooled fractions with a yield of $90.5 \%$. The overall yield is $16.8 \%$ based upon resin substitution. The products were characterized by RP-HPLC and Q-FT-ICR-MS. MS calculated for $\mathrm{C}_{83} \mathrm{H}_{129} \mathrm{~N}_{25} \mathrm{O}_{29} \mathrm{~S}_{4}$ [M+H] ${ }^{+}:$m/z 2068.834; found: 2068.811.
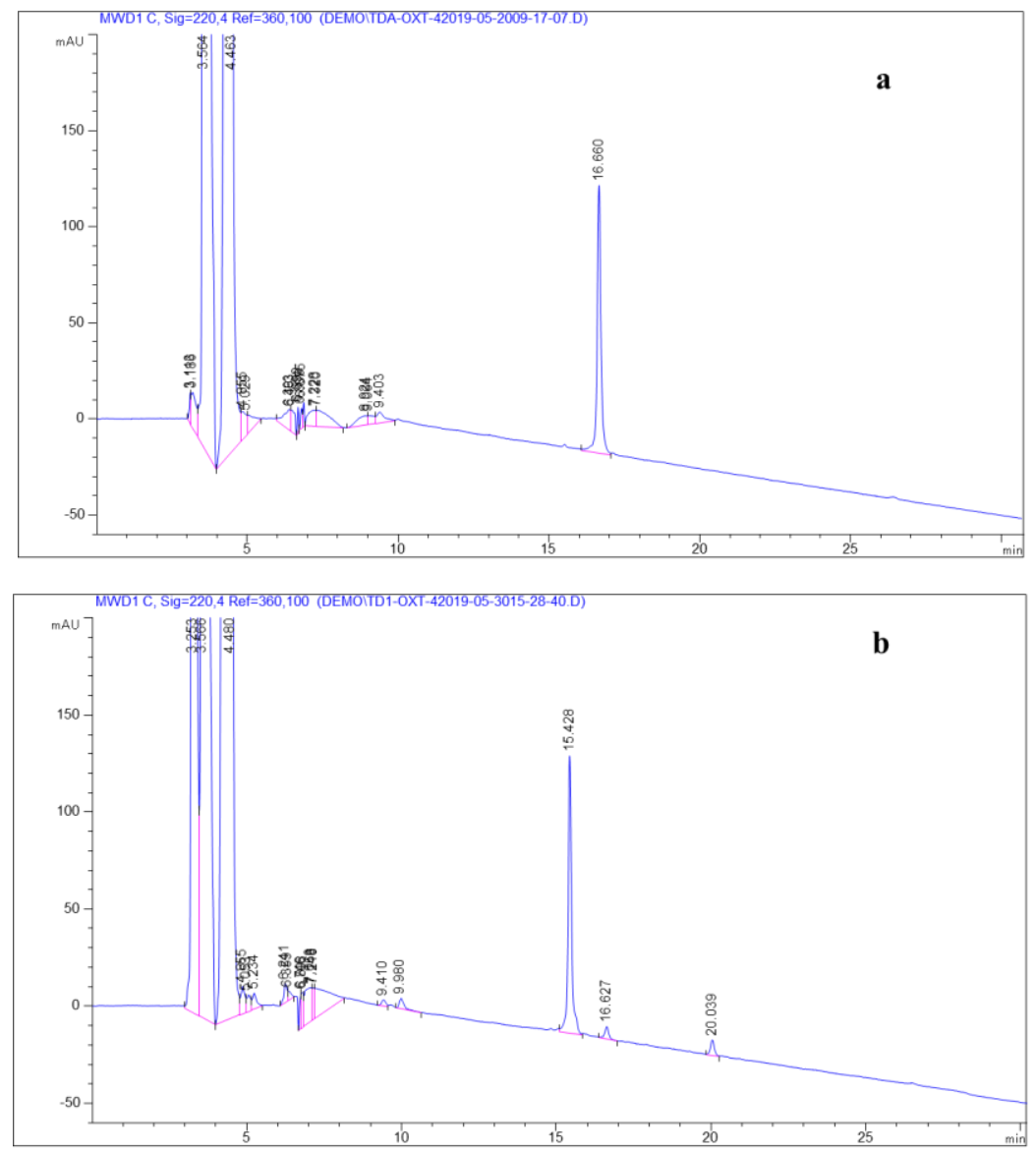


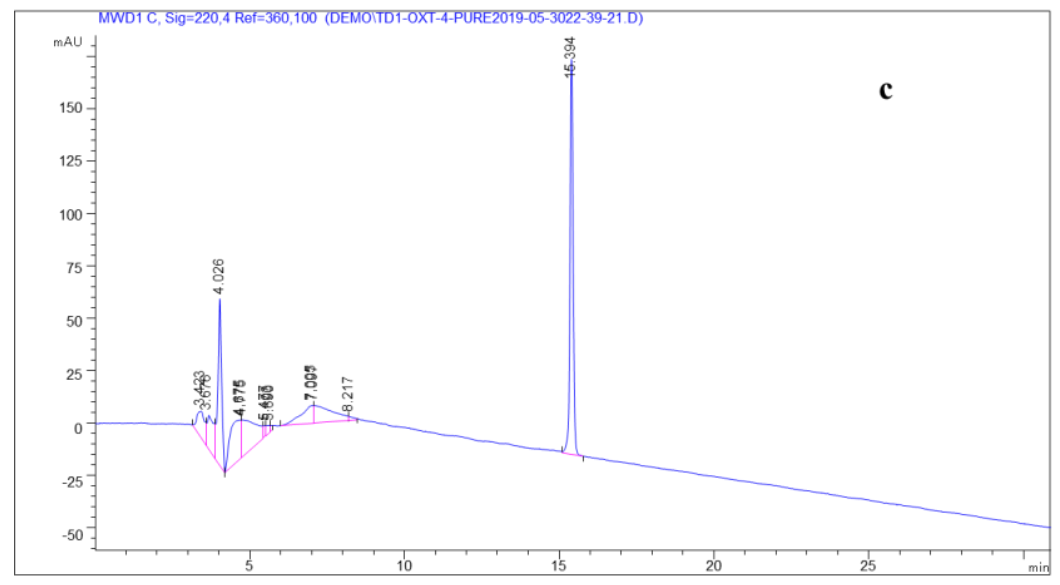

Figure 3. RP-HPLC chromatograms data. a) 11e; b) peptide II; c) purified peptide II. $\mathrm{CH}_{3} \mathrm{CN}-\mathrm{H}_{2} \mathrm{O}(0.1 \%$ TFA) as the eluent system $(1 \mathrm{~mL} / \mathrm{min}, 10 \%-40 \%, 30 \mathrm{~min})$ 
Q-FT-ICR-MS of peptide 11e, MS calculated for $\mathrm{C}_{89} \mathrm{H}_{141} \mathrm{~N}_{27} \mathrm{O}_{31} \mathrm{~S}_{4}[\mathrm{M}+\mathrm{H}]^{+}: \mathrm{m} / \mathrm{z}$ 2212.924; found: 2212.886 .

Mass Spectrum Molecular Formula Report

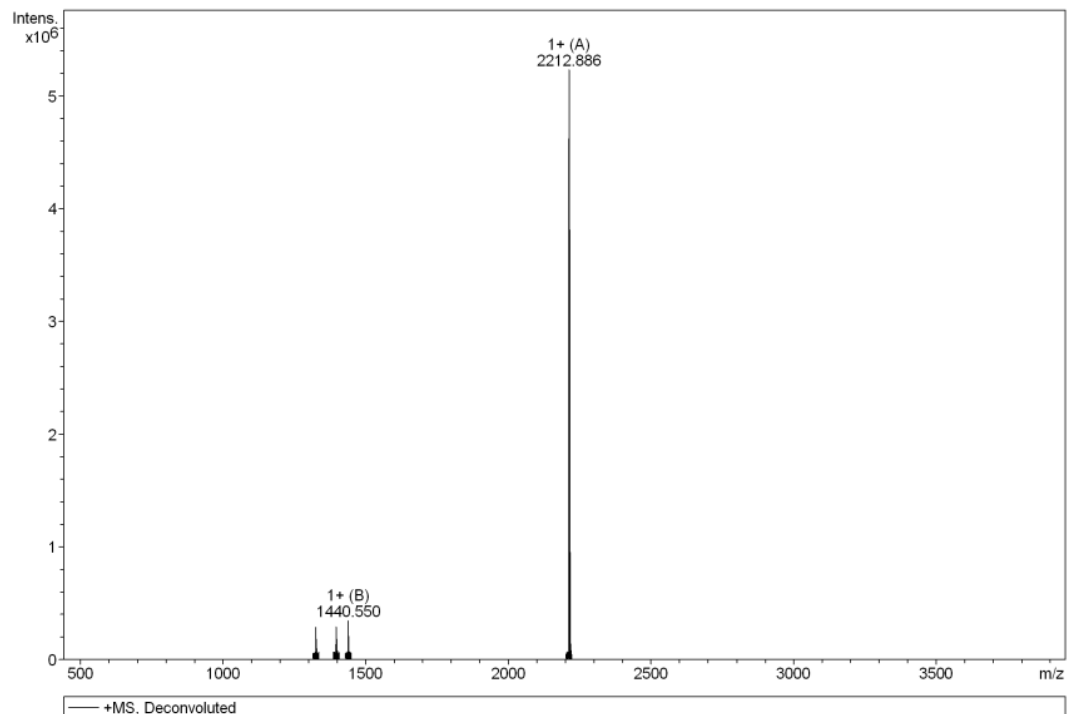

Table 'GenFormulaResults' could not be found in this analysis

Q-FT-ICR-MS of peptide II, MS calculated for $\mathrm{C}_{83} \mathrm{H}_{129} \mathrm{~N}_{25} \mathrm{O}_{29} \mathrm{~S}_{4}[\mathrm{M}+\mathrm{H}]^{+}: \mathrm{m} / \mathrm{z}$ 2068.834; found: 2068.811 .

Mass Spectrum Molecular Formula Report

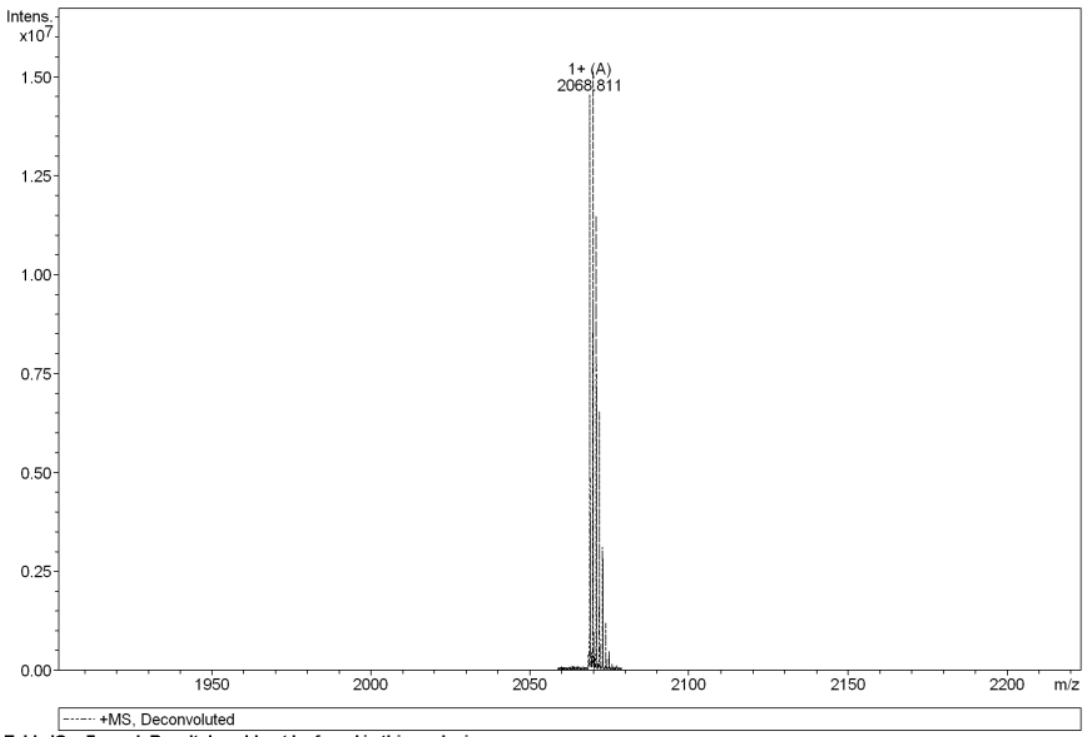

Table 'GenFormulaResults' could not be found in this analysis 


\section{Abbreviations}

$\mathrm{Ac}_{2} \mathrm{O}$ : Acetic Anhydride

Acm: Acetamidomethyl

BME: Beta-mercaptoethanol

CDI: $N$, $N$ '-Carbonyldiimidazole

DBU: 1, 8-Diazabicyclo [5.4.0] undec-7-ene

DHP: 3,4-Dihydro-2H-pyran

DIC: $N, N$ '-Diisopropylcarbodiimide

DIPEA: $N, N$-Diisopropylethylamine

DMAP: $N, N$-Dimethylaminopyridine

DMF: Dimethylformamide

DNTP: 2,2'-dithiobis(5-nitropyridine)

EDT: Ethanedithiol

ESI-MS: Electron-spray ionization mass spectrometry

$\mathrm{Et}_{2} \mathrm{O}$ : Diethyl ether

HATU: 2-(7-Azabenzotriazol-1-yl)- $N, N, N^{\prime}, N^{\prime}$-tetramethyluronium hexafluorophosphate

HOAc: Acetic acid

$\mathrm{MeOH}$ : Methanol

NMR: Nuclear magnetic resonance spectroscopy

Q-FT-ICR-MS: Quadrupole-Fourier transform ion cyclotron resonance mass spectrometry RP-HPLC: Reversed-phase high-performance liquid chromatography

SPPS: Solid phase peptide synthesis

TEA: Triethylamine

TFA: Trifluoroacetic acid

TfOMe: Methyl trifluoromethanesulfonate

TIS: Triisopropylsilane

Trt: Trityl

TsOH: $p$-Toluenesulfonic acid 